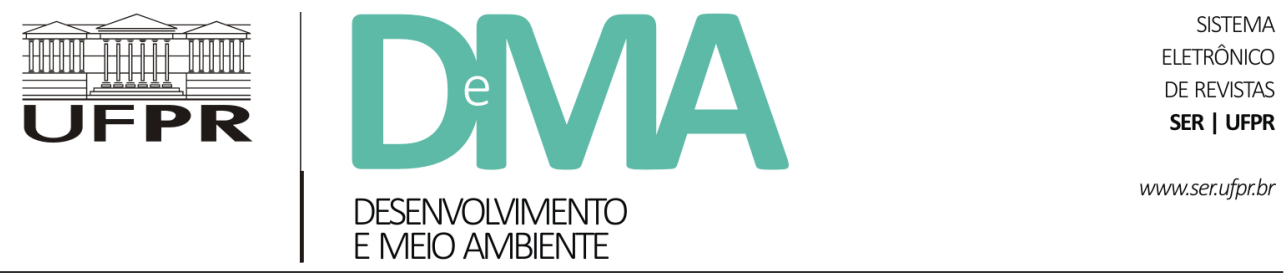

\title{
Eventos públicos, ganhos privados: limpeza urbana e gerenciamento de resíduos sólidos urbanos (RSU) no renascimento do Carnaval de rua paulistano
}

\section{Public Events, Private Gains: The Municipal Solid Waste (MSW) Management Amidst the Rebirth of Street Carnival in São Paulo}

\author{
Dumara Regina LIMA ${ }^{1 *}$, André Felipe SIMÕES ${ }^{1}$, Sonia Seger MERCEDES ${ }^{2}$ \\ ${ }^{1}$ Programa de Pós-graduação em Sustentabilidade, Escola de Artes, Ciências e Humanidades da Universidade de São Paulo (EACH), Univer- \\ sidade de São Paulo (USP), São Paulo, Brasil. \\ ${ }^{2}$ Instituto de Energia e Ambiente (IEE), Universidade de São Paulo (USP), São Paulo, Brasil. \\ *E-mail de contato: dumaralima@usp.br
}

Artigo recebido em 21 de janeiro de 2017, versão final aceita em 6 de outubro de 2017.

\begin{abstract}
RESUMO: Apesar de sua excepcionalidade, fugacidade e intangibilidade, os grandes eventos ganham cada vez mais relevância nas sociedades contemporâneas, apresentando-se muitas vezes como estratégia de promoção e desenvolvimento econômico das cidades e transformando-se em objeto de políticas públicas. Porém, no caso brasileiro, observados pela perspectiva da sustentabilidade, os grandes eventos também se transformam em grandes geradores de resíduos sólidos urbanos, comprometendo sua própria qualidade ambiental e envolvendo o trabalho precário de um grande número de catadores de materiais recicláveis, constituindo-se como um mecanismo perverso de exploração. Assim, entender sua dinâmica e organização torna-se fundamental para a busca de modelos sustentáveis de gestão e gerenciamento desses resíduos, considerando tanto seu aspecto ambiental como social e econômico. A partir de revisão bibliográfica, pesquisa documental, observação participante e documentação fotográfica, o presente trabalho discute o renascimento do Carnaval de rua na cidade de São Paulo, recentemente disciplinado pelo Decreto 56.690 de 7 de dezembro de 2015, sua transformação em grande gerador de resíduos e as lacunas de gestão no serviço de limpeza urbana e manejo dos resíduos sólidos da festa, tomando como referência a Política Nacional de Resíduos Sólidos. Os resultados indicam a necessidade de novas formas de organização da gestão e do gerenciamento dos resíduos sólidos urbanos de grandes eventos, por meio da implantação e do fortalecimento do arcabouço legal já constituído, o que envolve ações de educação ambiental, responsabilidade compartilhada e inclusão social de catadores.
\end{abstract}

Palavras-chave: catadores de materiais recicláveis; desigualdade socioeconômica; limpeza urbana; eventos de grande porte; Carnaval de rua de São Paulo; Política Nacional de Resíduos Sólidos. 
ABSTRACT: As well as exceptionality, fugacity and intangibility, urban mega-events achieve strong relevance in contemporary societies. Furthermore, such events usually emerge as a strategy for the promotion of cities and their economic development, and even become objects of public policies. However, in the Brazilian scenario, from the perspective of sustainability, mega-events may also generate large quantity of solid waste. These happenings may compromise the events' environmental quality and involve the precarious work of a large number of waste pickers, which constitutes a perverse mechanism of exploitation. Thus, the search of sustainable models of waste management becomes fundamental, in order to understand the dynamics and organization of these events, which must consider not only the environmental aspects, but also the social and economic ones. With this in mind, this work discusses the rebirth of Street Carnival in the city of São Paulo, recently disciplined by Decree 56.690/2015, its conversion into a large waste generator, and the management gaps of the urban cleaning service and handle of the party's solid waste., The study considered the National Policy of Solid Waste as a reference, and adopted bibliographic review, documentary research, participant observation and photographic documentation as research tools. The results suggest the need for new ways of organizing the management of the mega-events' solid waste, which may be solved through the implementation and strengthening of the legal framework already established. These strategies may involve actions of environmental education, shared responsibility and social inclusion of waste pickers.

Keywords: waste pickers; socioeconomic inequalities; urban cleaning; mega events; Street Carnival; National Solid Waste Policy.

\section{Introdução}

Apesar de sua excepcionalidade, fugacidade e intangibilidade, os eventos apresentam cada vez mais importância nas sociedades contemporâneas, ganhando, muitas vezes, materialidade com a construção de espaços próprios para sua realização. Megaeventos globais, como a Copa do Mundo e os Jogos Olímpicos, são atualmente seus corolários, capazes de transformar os eventos em grandes intervenções urbanas, cujos impactos vão além do período da sua realização e das cidades onde se realizam (Horne, 2010; Carvalho \& Gagliardi, 2015).

Para Montes \& Coriolano (2003), o aumento do número de eventos e de espaços específicos para sua realização "é fato que demonstra o desenvolvimento irreversível dessa atividade em todo o mundo" (Montes \& Coriolano, 2003, p. 43), destacando seu papel como regulador do mercado turístico, que sofre forte impacto da sazonalidade, e como produtor de imagem de uma cidade, estado ou país na captação de recursos públicos e investimentos. Associados à produção de imagem, à construção de identidade e à promoção dos lugares, os eventos, na contemporaneidade, assumem diferentes funções e, seja como base para o mercado turístico e imobiliário, como alavanca para a regeneração econômica (Waterman, 1998), ou como "experiência" que aumenta as oportunidades de consumo (Horne, 2010), tornam-se fatores estratégicos de diferenciação, integração e atratividade nos lugares em que se realizam (Castells \& Borja, 1996).

Tais características ganham especial relevância no período atual, marcado pela "condição paradoxal do processo de globalização que navega entre a tendência à homogeneização das sociedades [...] e a busca de preservação das identidades locais" (Vargas, 1998, p. 8), em um movimento que é tanto de padronização como de diversificação, de permanência e de flexibilidade, de centralização e descentralização, material e imaterial, entre outras oscilações próprias da pós-modernidade, em que 
"jamais há uma configuração fixa" (Harvey, 2008, p. 305).

É nesse quadro, da produção flexível, pós-industrial, pós-moderna, de avanço do setor terciário na centralidade da economia, quando a indústria turística se torna "a primeira no mundo, no que concerne à geração de recursos financeiros e emprego" (Vargas, 1998, p. 17), que os eventos se transformam em objeto de políticas públicas, envolvendo diferentes secretarias (Cabral et al., 2013; São Paulo, 2015; Frydberg et al., 2016), diferentes esferas de governo (Cabral et al., 2013), bem como parcerias no âmbito público-privado (Arruda, 2003; Horne, 2010, Frydberg et al., 2016), demandando organização cada vez mais complexa e especializada.

No entanto, observados pela perspectiva da sustentabilidade, os eventos se transformam em grandes geradores de resíduos sólidos das cidades e nas cidades. Entender sua dinâmica e organização torna-se fundamental para a busca de modelos sustentáveis de gestão e gerenciamento desses resíduos, não apenas porque "os resíduos acompanham o excesso e o luxo, mas, ao mesmo tempo, no mundo contemporâneo, constituem o principal meio e integram estratégias de subsistência e adaptação para a população que sofre privações" (Santos, 2014, p. 42), envolvendo importante dimensão ambiental e social.

Assim, por meio de revisão bibliográfica, pesquisa documental, observação participante e documentação fotográfica da festa realizada em
2016 e 2017, o presente trabalho discute o renascimento do Carnaval de rua de São Paulo (item 2), sua transformação em grande gerador de resíduos (item 3), as lacunas de gestão no serviço de limpeza urbana e manejo dos resíduos sólidos da festa (item 4) e os desafios e oportunidades para a efetivação da Política Nacional de Resíduos Sólidos no contexto dos eventos de grande porte (item 5).

\section{O renascimento do Carnaval de rua na cidade de São Paulo}

Para efeito deste trabalho, entende-se por renascimento do Carnaval de rua da cidade de São Paulo o resultado do processo que culminou com a publicação do Decreto Municipal 56.690 de 7 de dezembro de 2015 (São Paulo, 2015), que disciplina o Carnaval realizado em logradouros públicos na forma de blocos, bandas e cordões sob coordenação da Secretaria Municipal de Cultura ${ }^{1}$. Cabe destacar que o Carnaval foi oficializado na cidade na década de 1960, com a Lei Municipal 7.100 de 29 de dezembro de 1967 (São Paulo, 1967) e demais leis complementares que regulamentam as escolas de samba e outras manifestações carnavalescas atreladas à Secretaria Municipal de Turismo.

Se foge do escopo deste trabalho o encontro do Carnaval com o samba, o Carnaval negro, como descrito por Simson (2007), e a transformação dos primeiros blocos, bandas e cordões paulistanos em escolas de samba - cujo marco histórico é a

\footnotetext{
${ }^{1}$ O Decreto institui a Comissão Intersecretarial responsável pelo planejamento operacional do Carnaval de Rua da Cidade de São Paulo e estabelece competências. Coordenada pela Secretaria Municipal de Cultura, a Comissão é formada pelos seguintes órgãos e secretarias: Secretaria do Governo Municipal, São Paulo Turismo S.A. (SPTuris), Secretaria Municipal de Coordenação das Subprefeituras, Secretaria Municipal de Serviços, Secretaria Municipal da Saúde, Secretaria Municipal de Segurança Urbana, Secretaria Municipal de Transportes, São Paulo Negócios S.A. (SP Negócios), Secretaria Executiva de Comunicação, Secretaria Municipal de Direitos Humanos e Cidadania, Secretaria Municipal de Licenciamento, Secretaria Municipal de Desenvolvimento Urbano, Secretaria Municipal de Políticas para as Mulheres (São Paulo, 2015).
} 
fundação do Grupo Carnavalesco Barra Funda, em 1914, por Dionísio Barboza (Simson, 2007) -, é importante, ao menos, voltar ao Largo da Banana ${ }^{2}$, reduto do samba paulistano (Simson, 2007; Amarante, 2013; Azevedo, 2014), para estabelecer um paralelo que permita observar os distintos papéis do Carnaval popular nas políticas municipais e sua conformação no período atual. Como destaca Santos (2010, p. 62):

A análise histórica da relação entre as festas carnavalescas e os governos mostra que, na maioria das vezes, a administração pública e o carnaval estiveram sempre muito próximos, em relações às vezes consensuais, em outros momentos bastante conflituosas.

Se o reconhecimento do Carnaval de rua contemporâneo pela cidade de São Paulo se deu, aparentemente, em função do crescimento da festa nos últimos anos, fenômeno que ainda está para ser pesquisado e mais bem compreendido, o Carnaval do Largo da Banana, "gueto negro no bairro da Barra Funda", "elo histórico entre o êxodo dos antigos escravos do interior para a construção do desenvolvimento da cidade de São Paulo" (Souza, 2009, p. 342), precisou de mais de meio século para ser reconhecido pela cidade, em relações não raro conflituosas.
Tido como lugar "barra pesada" em função da pobreza de seus frequentadores (Azevedo, 2014), o Largo da Banana deu origem a diversos blocos e cordões carnavalescos (Simson, 2007). Também, a músicos como Geraldo Filme 3 , "corresponsável pela instituição do samba paulista" (Azevedo, 2012, p. 48), imortalizando os tempos do Largo da Banana, "onde nós fazia samba todas noites da semana" (Filme, 1968 apud Belo, 2008), na passagem do samba rural, vindo das senzalas do café, para o samba urbano do trabalho (Souza, 2009), e que fez do samba paulistano e sua mais tolerada expressão, o Carnaval, um campo de resistência e afirmação da cultura negra na cidade (Simson, 2007; Souza, 2009; Azevedo, 2014).

Do Largo da Banana até sua consagração, com a inauguração do sambódromo do Anhembi - Polo Cultural e Esportivo Grande Otelo -, em 1991, o Carnaval popular protagonizado pela população negra resistiu ao preconceito e à reprovação da sociedade, bem como à falta de recursos e à repressão policial $^{4}$ que marcaram a primeira fase do Carnaval de rua até sua regulamentação, em 1967 (Simson, 2007; Belo, 2008). Esse Carnaval se expandiu com a cidade, com a dispersão da população pobre em direção à periferia (Belo, 2008), materializou-se no espaço urbano com o sambódromo e se transformou,

\footnotetext{
${ }^{2}$ O Largo da Banana deu lugar, na década de 1980, ao Memorial da América Latina, exatamente onde se assenta o auditório Simón Bolívar (Amarante, 2013).

${ }^{3}$ Para Azevedo (2014, p. 341-345), "através de Geraldo se depara com uma vivência negra vibrante em São Paulo [...] me parece pertinente considerar memórias de sambistas que produziram canções que levaram em consideração espaços, saberes, hábitos dos lugares que viveram [...]. Com isto, a cidade de São Paulo desloca-se do lugar-ausente, que sempre lhe foi atribuída, quando se trata de samba. Entre os sambistas que cantaram a memória do lugar, destaca-se Geraldo Filme. A partir de sua história pessoal é possível repensar o mito do túmulo ou do lugar antimusical." O autor se refere à polêmica frase de Vinícius de Moraes e às representações da cidade como "túmulo do samba", destacando a necessidade de rearranjar as narrativas historiográficas que tratam da História musical do Sudeste. Curioso observar a ausência de Geraldo Filme na comissão de frente para a defesa do samba paulista, formada, frequentemente, por Adoniran Barbosa e o sambista zoólogo Paulo Vanzolini.

4 "Naquela época, a escola saía e a viatura saía atrás. Quando chegava lá em cima eles acabavam com o nosso samba. Pode parar! Pode parar! Hoje a polícia faz a segurança para nós". "Seu” Irineu, Componente da Velha Guarda da Escola de Samba Unidos de Vila Maria comparando o Carnaval do passado e o Carnaval atual. Entrevistado em junho de 2002 por Belo (2008, p. 41).
} 
tal como a cidade, que assiste, na aurora do século XXI, ao forte crescimento de blocos, bandas e cordões (Tabela 1) brotando, novamente, nas ruas da metrópole.

TABELA 1 - Blocos, bandas e cordões carnavalescos cadastrados na Secretaria Municipal de Cultura da cidade de São Paulo.

\begin{tabular}{cc}
\hline Ano & Blocos, Bandas e Cordões \\
\hline 2013 & 60 \\
2014 & 200 \\
2015 & 260 \\
2016 & 335 \\
2017 & 495 \\
\hline
\end{tabular}

FONTE: Rolnik (2015); São Paulo (2016a; 2016b). Elaboração própria.

A recente regulamentação do Carnaval de rua na cidade de São Paulo indica não só o crescimento do número de blocos carnavalescos ${ }^{5}$, como parece reforçar sua expansão. Com cadastro encerrado em 3 de novembro de 2016 para o Carnaval paulistano de 2017, foram contabilizados 495 blocos, bandas e cordões inscritos, com a ressalva:

Os blocos que utilizarem caminhões com mais de 3 metros de altura deverão comunicar esta necessidade, no momento do cadastro, para que a solicitação seja analisada pela CET e, uma vez aprovada, poderá fazer o pedido de autorização especial (São Paulo, 2016b).

Nota-se que são previstos grandes blocos, que em nossa observância do Carnaval de rua em 2016 e 2017, são também os grandes geradores de resí- duos. Há, atualmente, uma grande diversidade de origem, estilo musical e número de participantes dos blocos, bandas e cordões paulistanos. No entanto, se as lixeiras da cidade suportam os pequenos blocos (Figura 1), deixando apenas um rastro de alegria, os grandes blocos (Figura 2), que podem reunir 150 mil pessoas (Carnaval, 2017), as fazem transbordar, deixando um rastro de resíduos tão grande quanto seus carros de som e número de participantes.

No Carnaval reprimido dos tempos do Largo da Banana, que teve seu auge nas décadas de 1920 e 1930 (Azevedo, 2014), na "fase heroica" do Carnaval, em que os desfiles não contavam com reconhecimento e apoio oficial, eles só eram permitidos no domingo e na terça-feira gorda, pois sábado e segunda-feira de Carnaval eram dias normais de trabalho (Simson, 2007).

Atualmente, no período da produção flexível e da economia pós-industrial, o centro da economia se desloca da indústria para os serviços, com destaque para o setor de cultura, lazer e turismo (Vargas, 1998; Arantes, 2002). Com isso, pode-se observar em muitas cidades brasileiras a dilatação do tempo carnavalesco, como no Rio de Janeiro (Frydberg et al., 2016) e em São Paulo, com o popular pré-Carnaval (Figuras 3 e 4), já institucionalizado no calendário oficial em muitas cidades, assim como as micaretas - os carnavais fora de época, amplamente difundidos no Nordeste.

Sendo o Carnaval de $\mathrm{Momo}^{6}$ uma festa popular do Brasil urbano-industrial em formação - até mea-

\footnotetext{
${ }^{5}$ Processo também observado no Rio de Janeiro, com o ressurgimento de manifestações carnavalescas de rua após seu esvaziamento, provocado pela construção do sambódromo da Marquês de Sapucaí, em 1987 (Herschmann, 2013). Pode-se considerar a Marquês de Sapucaí paradigma dos demais sambódromos, bumbódromos e cirandódromos (Viana, 2005) na formatação de muitas festas populares brasileiras, o que a construção de espaços próprios para sua realização também favorece, de sobremodo, sua transmissão pela TV (Oliveira, 2007; Belo, 2008).

${ }^{6} \mathrm{O}$ Carnaval foi trazido ao Brasil no período colonial e era praticado por todas as camadas sociais como brincadeira de entrudo, "festa em que as pessoas se divertiam sujando umas às outras, com limões de cheiro, água suja, farinha, ovos, piche e outras substâncias" (Coutinho, 2006, p. 32).
} 


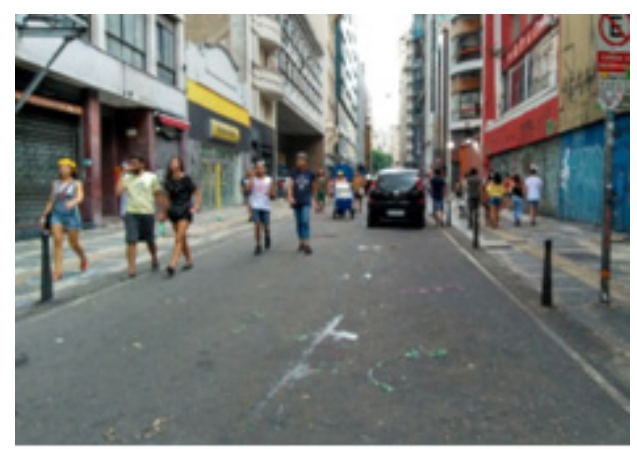

FIGURA 1 - Vista da rua após a passagem de pequeno bloco carnavalesco. Região central. Carnaval paulistano 2017.

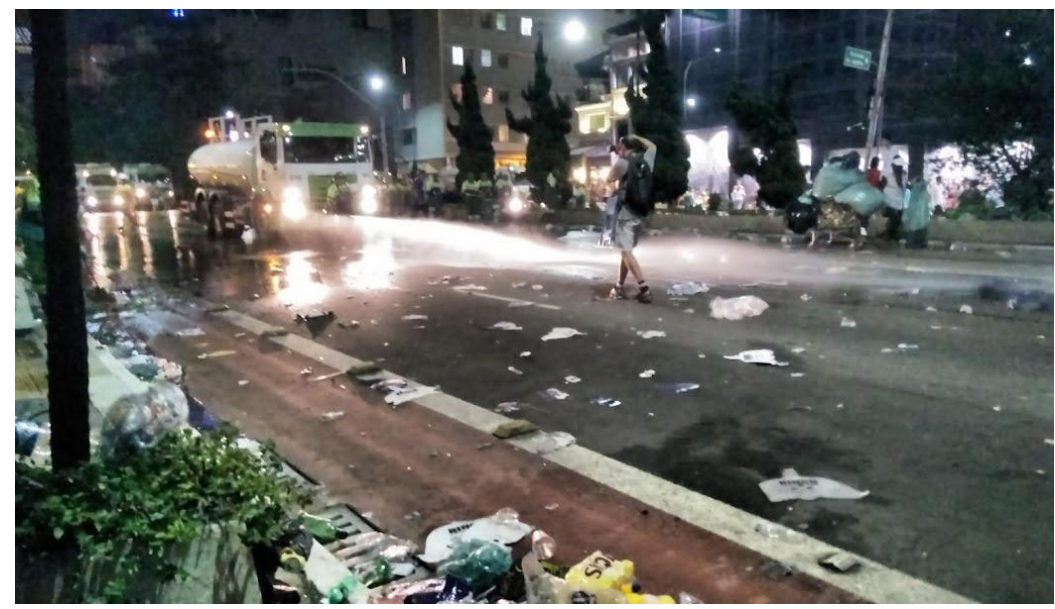

FIGURA 2 - Vista da rua após a passagem de grande bloco carnavalesco - imprensa e catador em meio à varrição hidráulica. Ao fundo, pessoal, máquinas e equipamentos do serviço público de limpeza urbana. Região central. Carnaval paulistano 2017

dos do século XIX, a maior festa popular brasileira era a Festa do Divino (Viana, 2005) -, a relação, primeiramente com os meios de comunicação e, posteriormente, com o comércio e a indústria local, destacando-se a cervejeira (Figura 5), teve papel preponderante na aceitação e estruturação do Carnaval popular paulistano a partir da década de 1930, "fase de institucionalização progressiva" (Simson,
2007). Isso culminou com sua oficialização em 1967, quando o poder público passou a organizar a festa como política de turismo e a formatá-la nos moldes do Carnaval carioca, até seu modelo atual de escolas de samba, que ganharam importância social, política e econômica (Oliveira, 2007; Belo, 2008). Porém, na atualidade, em que o Carnaval de rua renasce nas metrópoles do Sudeste - depois

Combatido fortemente no final do século XIX em diversas cidades brasileiras - por decretos, pela polícia e pelos jornais, deu lugar, como prática popular, aos ranchos, blocos e cordões carnavalescos no início do século XX, influenciados pelo Corso e pelo Carnaval de máscaras e salão da nova burguesia industrial brasileira de inspiração europeia, nos moldes de Veneza e Nice (Coutinho, 2006; Simson, 2007; Santos, 2010). 


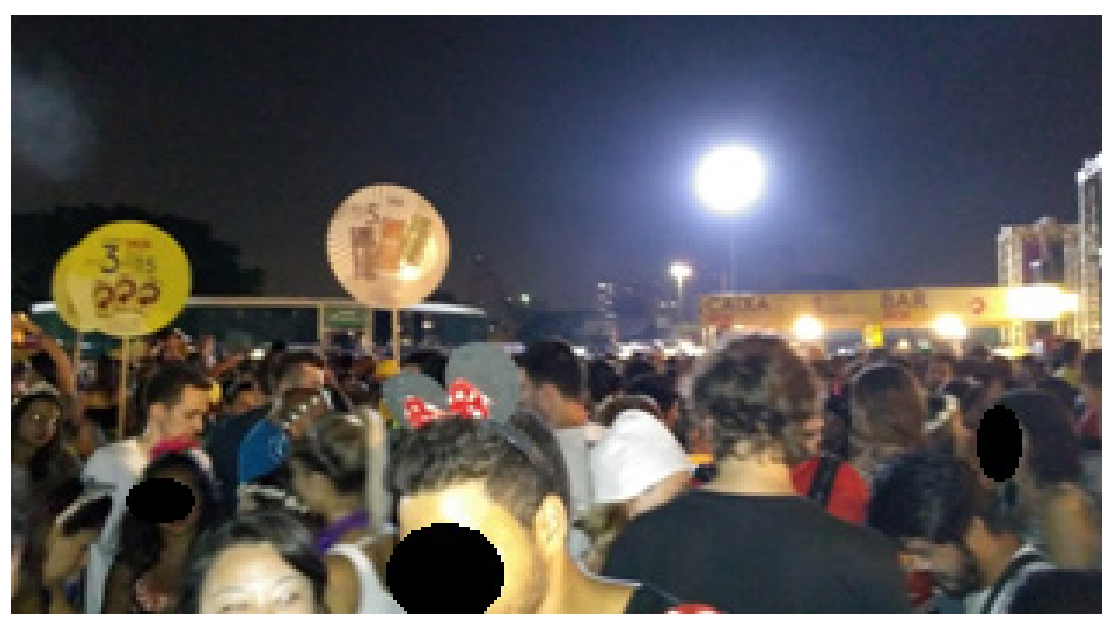

FIGURA 3 - Apresentação de grande bloco carnavalesco carioca no Memorial da América Latina, organizado por cervejaria, em 11/02/2017 - duas semanas antes do Carnaval no calendário cristão. Grande público.

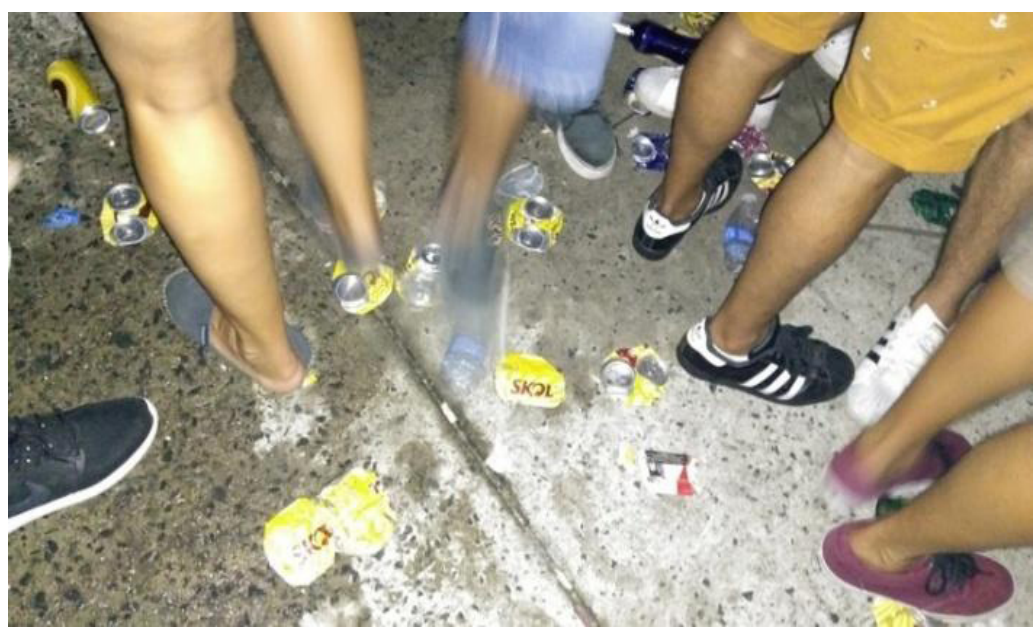

FIGURA 4 - Apresentação de grande bloco carnavalesco carioca no Memorial da América Latina, organizado por cervejaria, em 11/02/2017 - clareira com "solo exposto" e resíduos descartados no chão.

da apartação do Carnaval popular de rua com os sambódromos (Oliveira, 2007; Herschmann, 2013) - tanto os meios de comunicação como a indústria cervejeira, a qual se destaca pelo forte investimento em publicidade (Cervieri Junior et al., 2014), apresentam uma nova configuração, estabelecendo também novas relações com a festa, fenômeno social dinâmico por natureza (Amaral, 2012). Não se trata mais das crônicas carnavalescas e dos prêmios dos jornais, dos concursos de marchinhas de rádio (Coutinho, 2006; Simson, 2007). Trata-se já da apoteose do Carnaval espetáculo, quando as rela- 


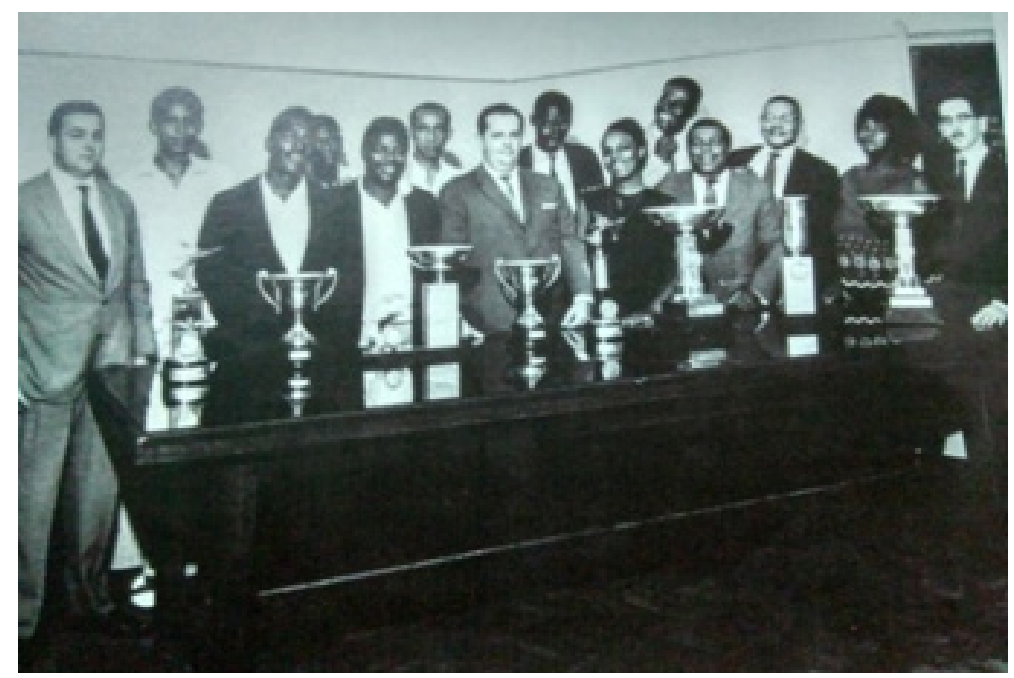

FIGURA 5 - Cúpula do samba paulista e três dirigentes da Companhia Antarctica Paulista em premiação do Carnaval na segunda metade da década de 1960. Período em que a cúpula dirigente do samba ainda era inteiramente negra.

FONTE: Simson (2007).

ções sociais são mediadas por imagens construídas (Debord, 1997) e "quando governantes e investidores passaram a desbravar uma nova fronteira de acumulação de poder e dinheiro - o negócio das imagens" (Arantes, 2002, p. 16).

Sobre o negócio das imagens, Moraes (2013) discute a convergência entre mídia, telecomunicações e informática na contemporaneidade, a oligopolização do setor e a mais-valia digital. Atuando de forma integrada em diferentes plataformas e suportes, contando com participação acionária e propriedades cruzadas em mídias de megaempresas, fundos de investimento, bancos e magnatas das finanças, com a "financeirização" do setor, os "megagrupos midiáticos detêm a propriedade dos meios de produção, a infraestrutura tecnológica, e as bases logísticas como parte de um sistema que rege habilmente os processos de produção material e imaterial" (Moraes, 2013, p. 21), tal como resíduos (materiais) de eventos (imateriais).

No Carnaval de rua contemporâneo paulistano, que "transborda" do sambódromo, espetacularizado em multiplataforma ${ }^{7}$ e patrocinado por corporações - em parcerias público-privadas mediadas por produtoras ${ }^{8}$ de eventos especializadas, que passam a organizar a festa junto com o poder municipal (Frydberg et al., 2016; São Paulo, 2016a) -, também não se trata mais de organização comunitária e

${ }^{7}$ As multiplataformas integradas se referem à “junção de interesses estratégicos em distintos suportes: papel, digital, áudio, vídeo e móvel” (Moraes, 2013, p. 21-22).

8 "Desde 2009, foi implantado no Rio de Janeiro um modelo de parceria público-privada para financiar e gerir o carnaval de rua da cidade. Esse modelo consiste na divulgação de um Caderno de Encargos e Patrocínios, com lançamento anual, que objetiva selecionar uma produtora com capacidade de gerir a festa. É responsabilidade dessa empresa, ao se candidatar para o Caderno, apresentar outras empresas interessadas em investir no carnaval de rua. Essas empresas são divididas pelo montante que oferecem para a realização da festa, sendo a cota master oferecida 
dos laços de vizinhança das primeiras agremiações carnavalescas (Simson, 2007; Belo, 2008). Tampouco da indústria cervejeira local, ou de disputas de cervejarias regionais (Harvey, 2009), em tempos de embalagens retornáveis.

A modernização do novo período técnico-científico-informacional, do uso intensivo da ciência, da tecnologia e da informação a serviço do consumo (Santos, 1997), também alcança a indústria nacional de bebidas na década de 1990, em que se destaca a cervejeira, que, em consonância com o período, concentra-se e compete em escala global (Harvey, 2009).

Sendo uma inovação no setor, as latas descartáveis e recicláveis de alumínio para bebidas, produzidas no Brasil a partir de 1991 (Andrade et al., 1998), criaram novas formas de produção, comercialização e consumo do produto (Cervieri Junior et al., 2014), bem como fomentaram o mercado de resíduos recicláveis, cujas "latas de alumínio" se tornaram um ícone da reciclagem no país (Layargues, 2002).

Se o início da década de 1990 foi marcado pela entrada das embalagens descartáveis e recicláveis de alumínio para bebidas, um novo objeto técnico que permitiu a flexibilização do consumo, o final da década foi marcado pela concentração do setor, com a união das rivais Brahma e Antarctica Paulista e a criação da Ambev, em 1999, sua fusão com a Belga Interbrew, com a criação da Inbev, em 2004, e sua fusão com a norte-americana Anheuser-Busch, da Budweiser, com a criação do Grupo AB-Inbev, em 2008 (Cervieri Junior et al., 2014). É no contexto de embalagens descartáveis, cervejarias globais, conglomerados de mídia em multiplataforma (Moraes, 2013) e parcerias público-privadas amparadas pela Lei Rouanet de incentivos fiscais à cultura da mesma década (Arruda, 2003) que o Carnaval popular renasce nas ruas das metrópoles do Sudeste, após sua projeção pelos sambódromos em escala nacional e internacional, na aurora da interatividade digital do Carnaval 2.0 (Marques \& Melo, 2015).

\section{Carnaval de rua: grande gerador de resíduos sólidos urbanos}

Instituída em 2010, após 21 anos de debates e disputas no Congresso Nacional, a Política Nacional de Resíduos Sólidos (PNRS) estabelece princípios, objetivos, instrumentos e diretrizes para a gestão dos resíduos sólidos no país. A rápida regulamentação, ocorrida no mesmo ano de sua aprovação - considerando que "são poucas as leis, neste país, que fo-

\footnotetext{
ao principal patrocinador. Em todos os anos de vigência desse modelo, a DreamFactory, empresa que também organiza outros grandes eventos na cidade, como o Rock in Rio e a Corrida da Ponte, venceu a licitação. E, nos últimos anos, foi a Ambev, empresa participante do maior grupo cervejeiro do mundo, a exercer o papel da patrocinadora master" (Frydberg et al., 2016, p. 5-6).

9 “A convergência, estimulada durante todo o ano na programação, tem um de seus pontos altos no modelo adotado para a transmissão dos desfiles. O carnaval transmitido pela TV Globo, também é veiculado na íntegra, ao vivo, pelo site G1, da Globo.com. Nessa transmissão on-line o usuário é capaz de interagir através das redes sociais: Facebook, Twitter, Whatsapp e Google+, tecendo comentários, enviando fotos diretamente do seu smartphone, ou através de tablet ou um computador com acesso à internet [...]. Diante desse novo cenário, nasce o que chamamos de "Carnaval 2.0", que se configura como aquele Carnaval que passou a ser também transmitido no universo on-line, pelo site do G1, propagado e disseminado em ambiência das redes sociais da Web 2.0 de forma colaborativa e participativa pelos usuários. Nessa nova relação que se constitui entre empresa responsável pela transmissão e usuários passou a existir uma nova produção de sentido em torno da festa carnavalesca, agora menos estanque, e com maior participação dos “espectadores” (Marques \& Melo, 2015, p. 9-10).
} 
ram regulamentadas no mesmo ano da sua sanção" (Costa, 2014, p. 159) - contrasta com a lentidão de sua publicação, especialmente se comparada ao conjunto de leis ambientais ${ }^{10}$ que, assim como a PNRS, também integram a Política Nacional do Meio Ambiente.

Classificando os resíduos quanto à origem e à periculosidade, a PNRS trata de uma gama diversa de resíduos, entre os quais os Resíduos Sólidos Urbanos (RSU), em que se enquadram os resíduos domiciliares e os resíduos de limpeza urbana - os originários da varrição, limpeza de logradouros e vias públicas e outros serviços de limpeza urbana, já tratados na Política Nacional de Saneamento, instituída pela Lei . $^{\circ} 11.445 / 2007$, e incorporados pela PNRS (Brasil, 2007; 2010). Destaca-se que o serviço de limpeza urbana e manejo de RSU é considerado, pelo novo marco do saneamento de 2007, serviço de saneamento básico (Brasil, 2007).

Ao serem realizados no espaço público, os grandes eventos geram resíduos que demandam um serviço especial de varrição, limpeza de logradouros e vias públicas e de manejo de resíduos, em função tanto de sua excepcionalidade como do volume de resíduos gerados - trata-se de um serviço especial de limpeza urbana e de resíduos sólidos urbanos especiais. Conforme a Política Estadual de Resíduos Sólidos do Estado de São Paulo (São Paulo, 2006):

$2 .^{\circ}$ - Poderão ser instituídas taxas e tarifas diferenciadas de serviços especiais, referentes aos resíduos que: 1. Contenham substâncias ou componentes potencialmente perigosos à saúde pública e ao meio ambiente; 2. Por sua quantidade ou suas características, tornem onerosa a operação do serviço público de coleta, transporte, tratamento e disposição final dos resíduos urbanos.

No Plano de Apoio ao Carnaval de rua de 2016 (São Paulo, 2016a), a Prefeitura de São Paulo declarou o contingente de 2.100 agentes de limpeza e o uso de 230 equipamentos para a limpeza. Foi o maior contingente de trabalhadores, considerando os 1.700 agentes de trânsito e 2.000 guardas metropolitanos. Em 2017, a Prefeitura declarou 1.506 funcionários para limpar as ruas após a passagem dos blocos, em um investimento de cerca de 2,5 milhões com varrição e 2.900 agentes de trânsito (São Paulo, 2017), indicando também as variações do contingente de trabalhadores a cada festa e/ou administração municipal.

Além desses trabalhadores atuantes na limpeza formal da festa, somam-se os catadores informais de "latinhas", que realizam a coleta seletiva das latas descartáveis de alumínio para bebidas. Desde 2001, o Brasil é campeão mundial de reciclagem de latas de alumínio (Abralatas, 2016), em que se destaca a atividade desses trabalhadores, inseridos de forma precária no serviço de limpeza da festa.

Pode-se, assim, considerar os eventos de grande porte realizados nos espaços públicos da cidade como grandes geradores de RSU. Os geradores possuem um importante papel na PNRS, sobretudo, aqueles que "gerem resíduos que, mesmo caracterizados como não perigosos, por sua natureza, composição ou volume, não sejam equiparados aos

\footnotetext{
${ }^{10}$ Para Little (2003), a década de 1990 marca significativos avanços na política ambiental do país, destacando a inserção da temática ambiental na agenda política nacional, o crescimento do setor ambiental governamental e a promulgação de uma série de leis ambientais, como a Política Nacional de Recursos Hídricos (Lei 9.433 de 1997), a Lei de Crimes Ambientais (Lei 9.650 de 1999) e a Lei do Sistema Nacional de Unidades de Conservação (Lei 9.985 de 2000). Nota-se que a PNRS foi publicada apenas em 2010.
} 
resíduos domiciliares pelo poder público municipal" (Brasil, 2010).

Tais geradores estão sujeitos à elaboração de plano de gerenciamento de resíduos, que deve conter, entre outros, a identificação das soluções consorciadas ou compartilhadas com outros geradores; ações preventivas e corretivas a serem executadas em situações de gerenciamento incorreto ou acidentes, metas e procedimentos relacionados à minimização da geração de resíduos sólidos e à reutilização e reciclagem, ações relativas à responsabilidade compartilhada pelo ciclo de vida dos produtos e medidas saneadoras dos passivos ambientais relacionados aos resíduos sólidos (Brasil, 2010).

A PNRS, embora não trate especificamente de resíduos gerados em eventos, atribui aos Pla- nos Municipais de Resíduos Sólidos a tarefa de identificação dos resíduos sólidos e dos geradores sujeitos a plano de gerenciamento específico (Brasil, 2010).

Publicado em 2014, o Plano de Gestão Integrada de Resíduos Sólidos (PGIRS) do município de São Paulo ${ }^{11}$ reconhece "a necessidade de desenvolvimento de Planos de Gerenciamento de Resíduos Sólidos pelos responsáveis por grandes eventos e feiras que ocorram na cidade", os quais devem conter, entre outros, os compromissos do responsável com a segregação integral dos resíduos e sua coleta seletiva, a ativação da logística reversa sempre que necessária, as metas para redução da presença de seus resíduos em aterros (São Paulo, 2014, p. 49).

Metas ambiciosas, quando se observa a gera-

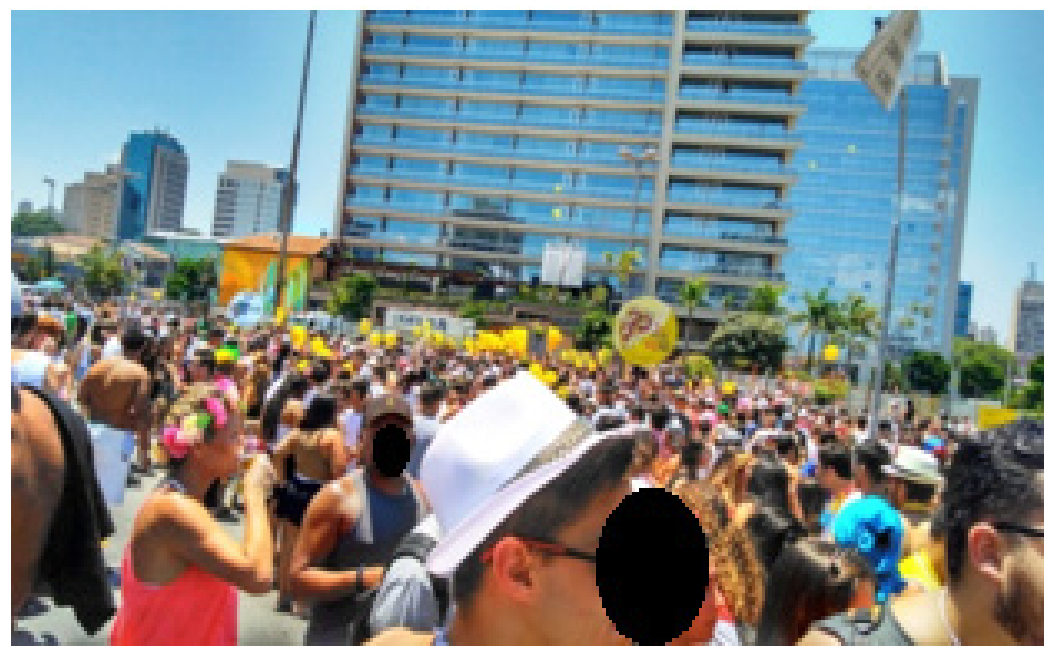

FIGURA 6 - A “onda amarela” do Carnaval de rua paulistano em alusão à "onda azul” identificada por Frydberg, Kossak \& Machado (2016) no Carnaval de rua carioca - autores destacam exibição de marca de cerveja patrocinadora sobre uma das maiores expressões populares da cidade. Largo da Batata. Carnaval paulistano 2017.

${ }^{11}$ O PGIRS 2014 atende à Política Nacional de Resíduos Sólidos, Lei Federal de Saneamento Básico, Política Nacional sobre Mudanças do Clima e Política Nacional de Educação Ambiental. 


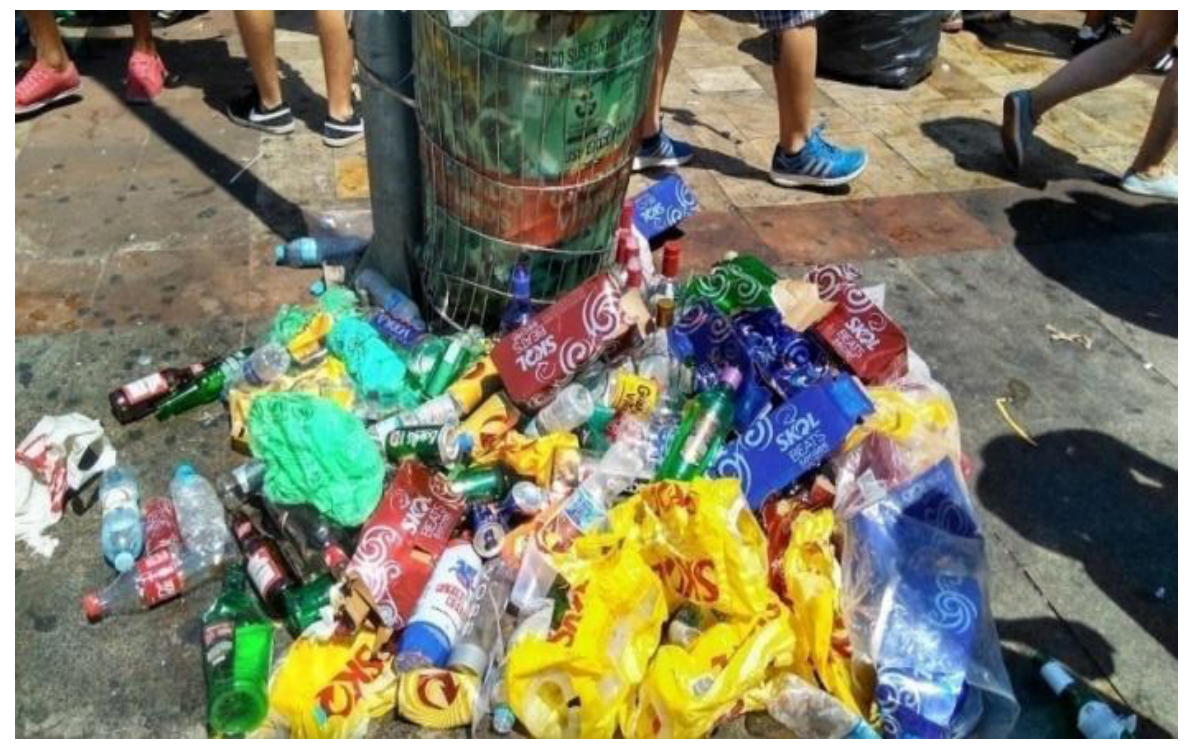

FIGURA 7 - Resíduos descartados próximo à lixeira saturada e a "onda amarela” no chão do Largo da Batata. Resíduos de embalagens de bebidas diversas e do comércio de bebidas ambulante de exclusividade do patrocinador. Carnaval paulistano 2017.

ção, a disposição e a coleta de resíduos sólidos urbanos dos eventos de grande porte realizados no espaço público da cidade, como o Réveillon na Paulista, a Virada Cultural, a Parada do Orgulho LGBT e a Corrida de São Silvestre. Sobretudo aqueles que, além do grande público, envolvem vasta cobertura de mídia, produtoras de evento especializadas, patrocínios vultosos e campanhas publicitárias (Figura 6), cujo marketing direto aumenta a geração de resíduos, para os quais o mobiliário urbano permanente se mostra insuficiente, como o Carnaval de rua (Figura 7).
Mesmo considerando-se os planos de gerenciamento para grandes geradores, em que se inserem ações relativas à responsabilidade compartilhada pelo ciclo de vida dos produtos ${ }^{12}$, bem como taxas e tarifas diferenciadas de serviços especiais que tornem onerosa a operação do serviço público de limpeza urbana, presentes na legislação, a responsabilidade sobre os resíduos sólidos urbanos gerados no Carnaval de rua paulistano em $2016^{13}$ e 2017 ficaram a cargo do poder público municipal (São Paulo, 2015b; São Paulo, 2017).

Com algumas variações, a contrapartida da

\footnotetext{
${ }^{12}$ Conforme a PNRS (Brasil, 2010), a responsabilidade compartilhada pelo ciclo de vida dos produtos é conjunto de atribuições individualizadas e encadeadas dos fabricantes, importadores, distribuidores e comerciantes, dos consumidores e dos titulares dos serviços públicos de limpeza urbana e de manejo dos resíduos sólidos, para minimizar o volume de resíduos sólidos e rejeitos gerados, bem como para reduzir os impactos causados à saúde humana e à qualidade ambiental decorrentes do ciclo de vida dos produtos.

${ }^{13}$ Em ata de reunião realizada em 7/12/2015, a Secretaria Municipal de Cultura discrimina em resumo a responsabilidade do parceiro, não se incluindo a limpeza urbana (São Paulo, 2015b, p. 52).
} 
empresa parceira que realiza e comercializa o evento, fazendo a captação de patrocínio (Frydberg et al., 2016), refere-se à instalação de banheiros químicos, serviço médico - ambulâncias, credenciamento de vendedores, proteção de jardins e monumentos, expedição de guia de blocos, palco cultural, programação visual e divulgação, como no Carnaval de rua de 2016 (São Paulo, 2015b). A ausência de responsabilidade compartilhada sobre os resíduos, no entanto, reflete-se na ausência de ações de inclusão de catadores, bem como no comprometimento do saneamento e da qualidade ambiental da festa, que passa a ser analisado.

\section{O chão da festa}

Em uma primeira aproximação dos RSU gerados no Carnaval de rua de São Paulo, apresenta-se algumas características da limpeza urbana e do manejo de RSU passíveis de observação empírica no espaço da festa. Toma-se como referência a sequência de etapas do gerenciamento de resíduos, que compreende a geração, o acondicionamento, o armazenamento, a coleta, o transporte, a triagem, o tratamento, a valorização e o destino final (Viana et al., 2015).

Com relação ao Carnaval, a geração de RSU se dá ao longo de todo o espaço-tempo da festa, reforçada pela forte presença de vendedores ambulantes de bebidas credenciados, que podem tanto acompanhar os blocos (Figura 8) como se "fixar temporariamente" em pontos de grande circulação (Figura 9), contando também com máquinas de cartão de crédito sem fio, de uso generalizado. $\mathrm{O}$ estímulo ao consumo de bebidas é ainda promovido por propagandas, via patrocínio tanto da festa

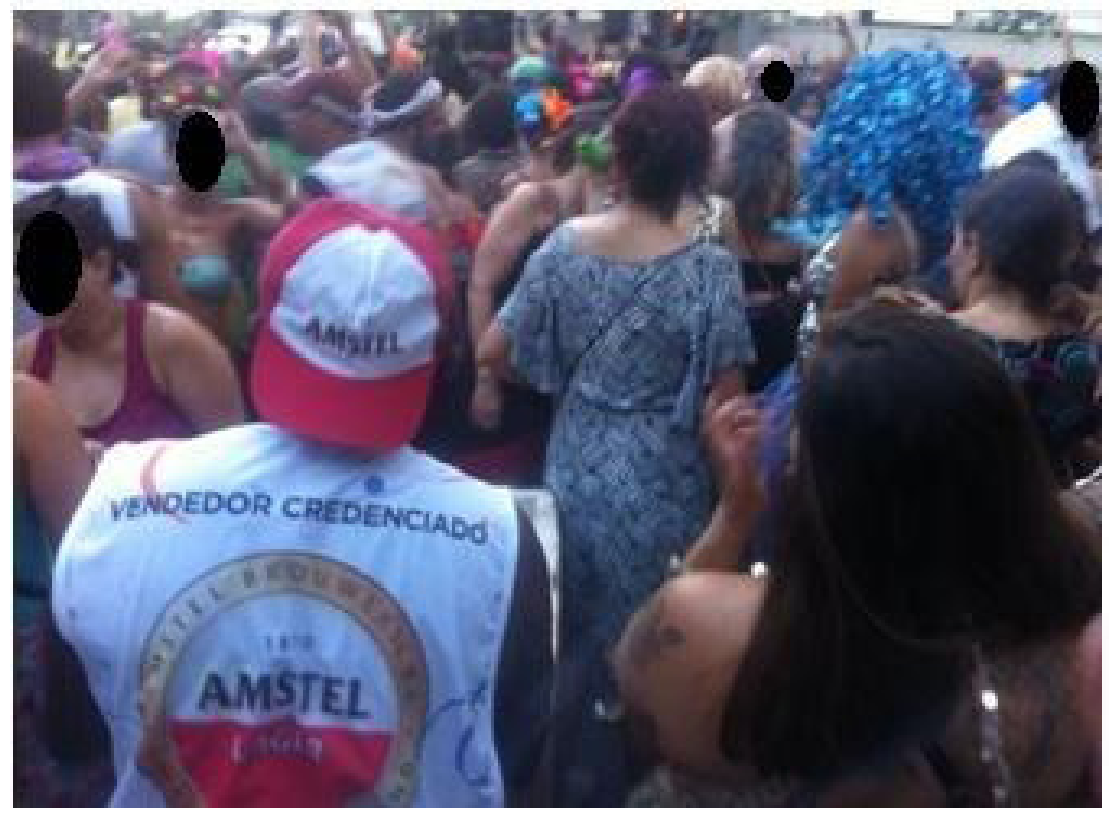

FIGURA 8 - Promoção e comercialização de bebidas por ambulante em bloco carnavalesco. Carnaval paulistano 2016. 


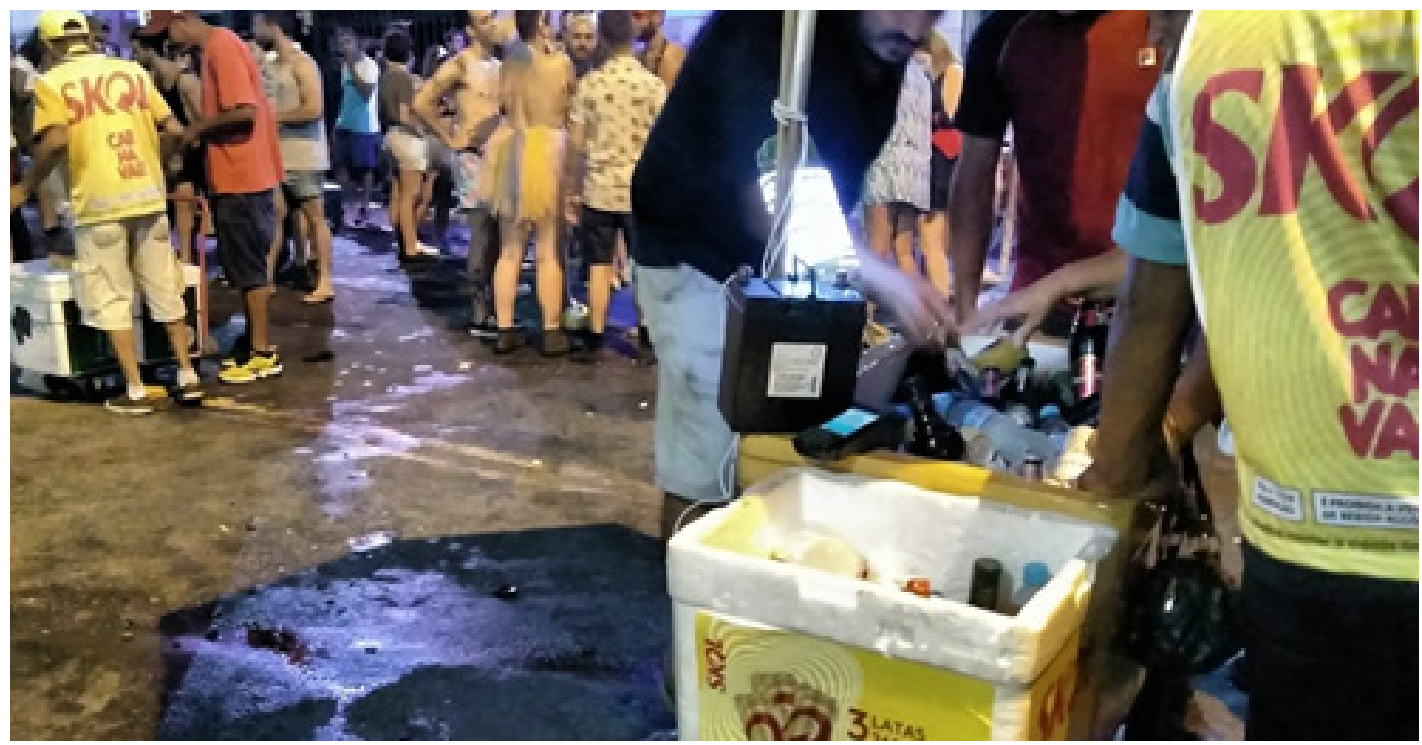

FIGURA 9 - Promoção e comercialização de bebidas por ambulantes em ponto de grande circulação e o uso de máquina de cartão de crédito. Carnaval paulistano 2017.

como dos blocos, que também podem receber patrocínio direto (São Paulo, 2015a). No entanto, a exclusividade na comercialização e no cadastro de ambulantes se insere no programa de patrocínio da festa, definido a cada ano/edital.

Em 2016, após a regulamentação da festa, o primeiro patrocínio envolveu a promoção e ativação de marca pouco conhecida do grupo Heineken no Brasil ${ }^{14}$, e em 2017, de marca já estabelecida do grupo AB-Inbev. No entanto, observou-se que as duas marcas estiveram presentes no Carnaval paulistano de 2016 e 2017, porém, com participação distinta. Em 2016, o grupo Heineken patrocinou a festa, tendo exclusividade na comercialização dos seus produtos e divulgação de sua marca, enquanto o grupo $\mathrm{AB}$-Inbev estampou sua marca com o patrocínio de grandes blocos (Figura 10), invertendo-se a posição em 2017.

Isso mostra a competição entre corporações globais pela festa, bem como as diferentes formas de participação das marcas/empresas. Destaca-se que, em 2016, o patrocínio foi de 3,5 milhões, e em 2017, de 15 milhões (São Paulo, 2017), indicando também o crescimento da festa - organizada com a expectativa de público de dois milhões de pessoas em 2016 (São Paulo, 2016a), e de três milhões em 2017 (São Paulo, 2016c).

Composto em grande parte por embalagens descartáveis de bebidas (Figuras 11 e 12), os RSU são gerados na concentração, no percurso e na dis-

\footnotetext{
14 “A cerveja Amstel foi criada em 1870, às margens do rio de mesmo nome, em Amsterdã. A cerveja é fruto da paixão de dois amigos [...], se tornou extremamente popular e está presente em mais de 90 países [...]. Chegou ao Brasil em 2014 e está disponível em versão chope, em garrafa $600 \mathrm{ml}$ e em latas 350ml, 269ml e 473ml”. Disponível em: <http://www.heinekenbrasil.com.br/nossas-marcas/cervejas/amstel $>$.
} 


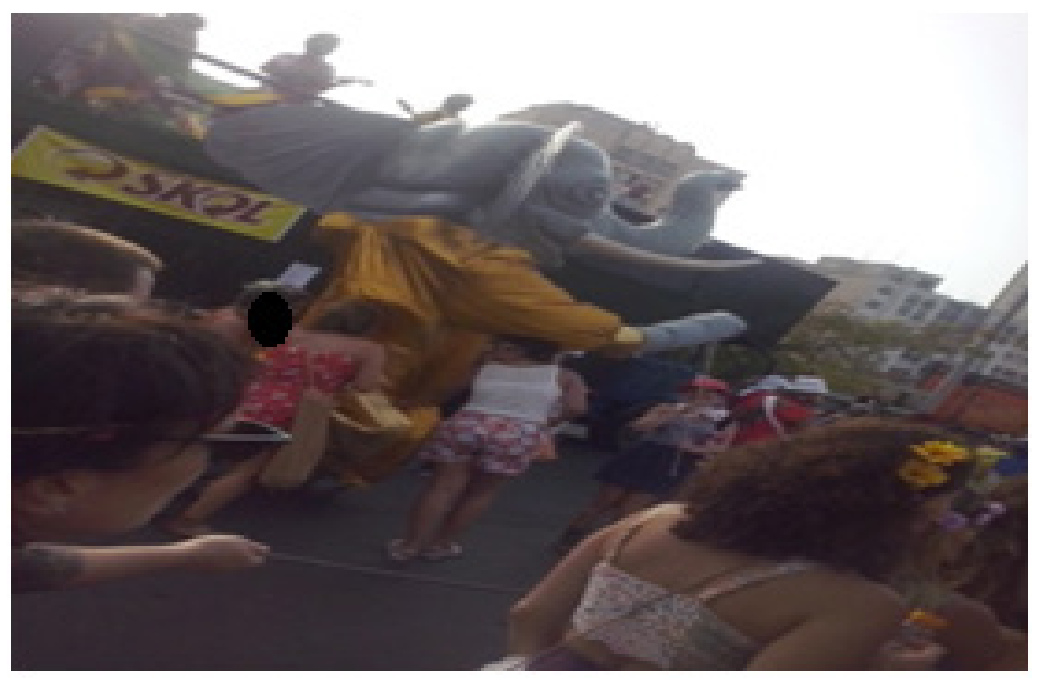

FIGURA 10 - Ativação de marca da AB-Inbev no Carnaval de rua de São Paulo em 2016 por meio de patrocínio de grande bloco. Carnaval paulistano 2016.

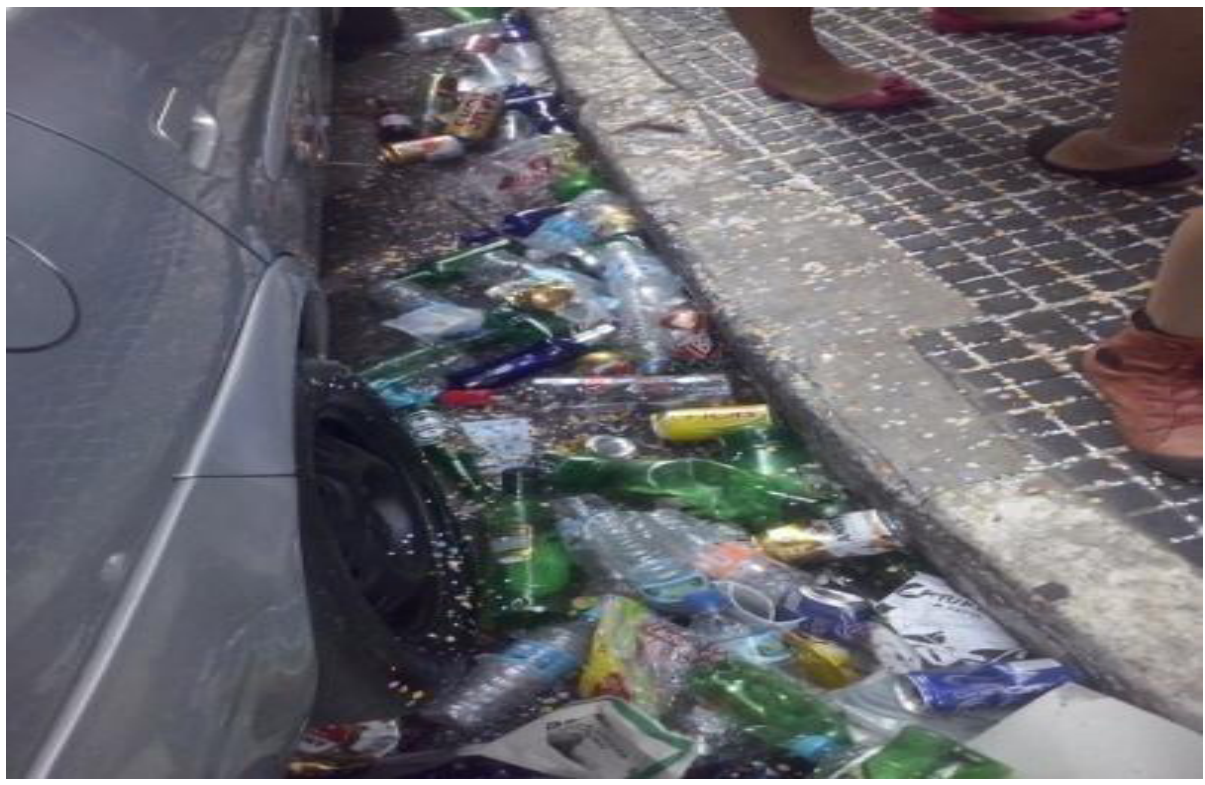

FIGURA 11 - RSU gerado no Carnaval paulistano 2016. 


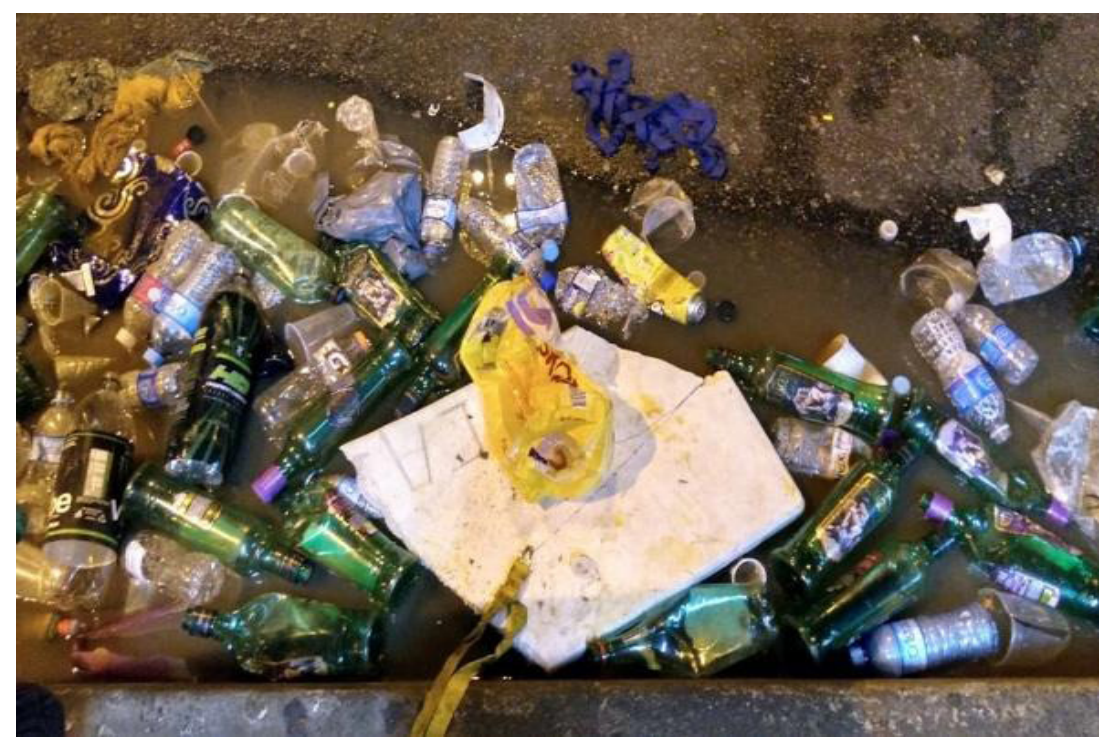

FIGURA 12 - RSU gerado no Carnaval paulistano 2017.

persão dos blocos carnavalescos e seu entorno, bem como nos palcos, com diversas atrações ${ }^{15}$. Em 2016, foram montados palcos nas cinco macrorregiões da cidade (São Paulo, 2016a), e em 2017, foram reduzidos para dois: Anhangabaú, região central, e Largo da Batata, zona oeste, em que se concentra o maior número de blocos, bandas e cordões, cujos palcos auxiliam na dispersão dos foliões (São Paulo, 2017).

Como o descarte é imediato ao consumo, a ausência de uma estrutura especial de lixeiras para a festa faz com que elas sejam rapidamente saturadas (Figuras 13 e 14), de modo que o descarte e acondicionamento dos resíduos pelos consumidores-foliões seja feito em grande parte no chão, os quais, com o movimento dos passantes, vão se acu- mulando nas sarjetas (Figuras 11, 12, 13 e 14). Com relação ao trabalho dos catadores, a coleta das latas de alumínio se dá nas lixeiras, as quais ganham maior vida útil, mas, sobretudo, no chão e nas sarjetas (Figuras 13 e 15), em que também se verifica um primeiro tratamento do material, sendo mais comum a redução das latas com a força das mãos ou dos pés. Existe uma diversidade de formas de acondicionamento, armazenamento e transporte das latas descartadas de alumínio pelos catadores, com o uso de carroças (Figura 13) ou carrinhos de supermercado (Figura 2). No entanto, o mais comum, em eventos, é o acondicionamento, armazenamento ou transporte em sacos e mochilas (Figura 16), que permitem maior circulação pelos espaços de grande aglomeração.

\footnotetext{
${ }^{15}$ A programação é amplamente difundida na internet e em grandes banners pela cidade. Em 2017, a PMSP também lançou um aplicativo (com as cores do patrocinador) com a programação oficial nas ruas e nos palcos, mapa, agenda, uma selfie (como a campanha do Carnaval 2017 \#apaixonadoSPelafolia e voltada para a diversidade de gênero), além de informações sobre blocos e utilidades - com informações turísticas, telefones úteis, aeroportos, hospitais e delegacias.
} 
A coleta seletiva das latas acompanha sua geração nos blocos carnavalescos e se dá ao longo de todo o espaço-tempo da festa, com a segregação na fonte geradora efetuada pelos catadores informais. Realizando um tipo de "coleta e comercialização imediata ao descarte", em que se pode observar sucatarias da região central funcionando diuturnamente no período festivo - esses trabalhadores ativam um sistema ótimo de logística reversa ${ }^{16} \mathrm{em}$ qualidade e volume, organizado e controlado em escala global por um pequeno grupo de corporações do setor metalúrgico (Andrade et al., 1998; Lima, 2007; Abralatas, 2009) -, que, sem o exibicionismo publicitário e competitivo das cervejarias, participam da festa com o brilho próprio do alumínio, que por meio do monopólio das chapas (Abralatas, 2009), estampam todas as cores, rótulos e símbolos. A limpeza formal do Carnaval de rua pelo poder público, que no caso da cidade de São Paulo corresponde ao pagamento pela limpeza pública e manejo de RSU à empresa concessionária (Godoy, 2015), ou seja, o serviço de limpeza e manejo que é remunerado pelo poder público municipal - no caso, à empresa Inova, em ambos os carnavais observados - realiza-se apenas ao final dos desfiles e do dia, com a varrição e o acondicionamento, sem separação por material, de RSU (Figura 17) em sacos sem nenhum tipo de identificação.

No caso do Carnaval de rua paulistano observado em 2016 e 2017, não há coleta seletiva na fonte

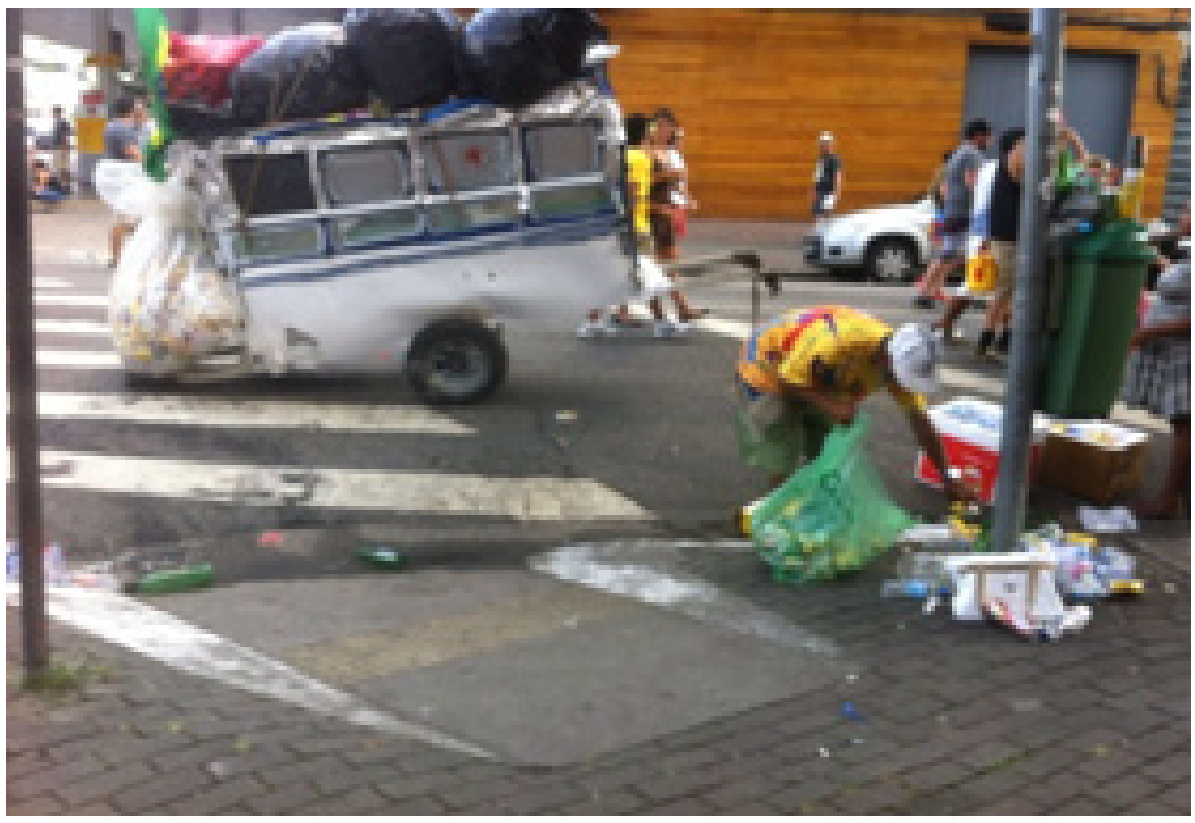

FIGURA 13 - Lixeira saturada e catador. Zona Oeste. Carnaval paulistano 2016.

\begin{abstract}
${ }^{16}$ A logística reversa é definida na PNRS como instrumento de desenvolvimento econômico e social caracterizado por um conjunto de ações, procedimentos e meios destinados a viabilizar a coleta e a restituição dos resíduos sólidos ao setor empresarial, para reaproveitamento, em seu ciclo ou em outros ciclos produtivos, ou outra destinação final ambientalmente adequada (Brasil, 2010).
\end{abstract}




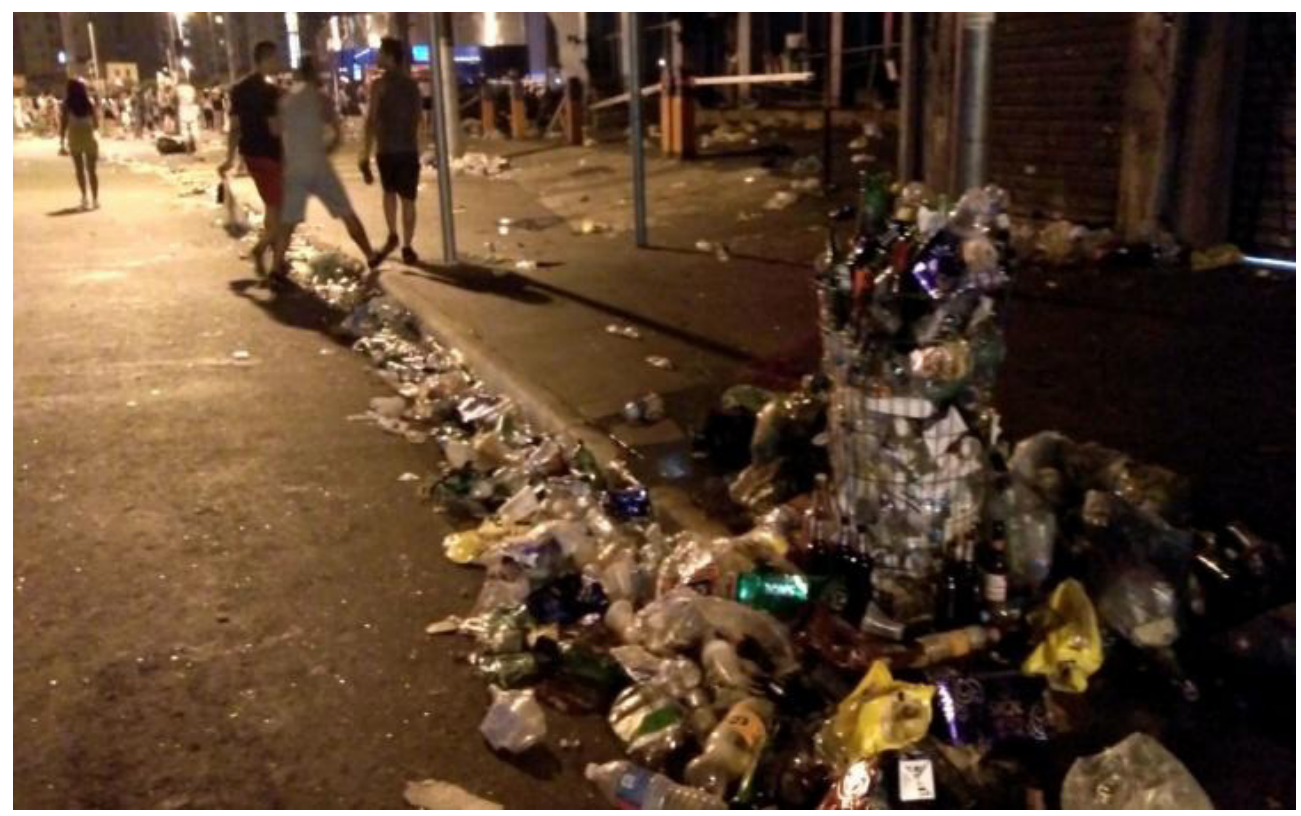

FIGURA 14 - Lixeira saturada e RSU acondicionados na sarjeta. Zona Oeste. Carnaval paulistano 2017.

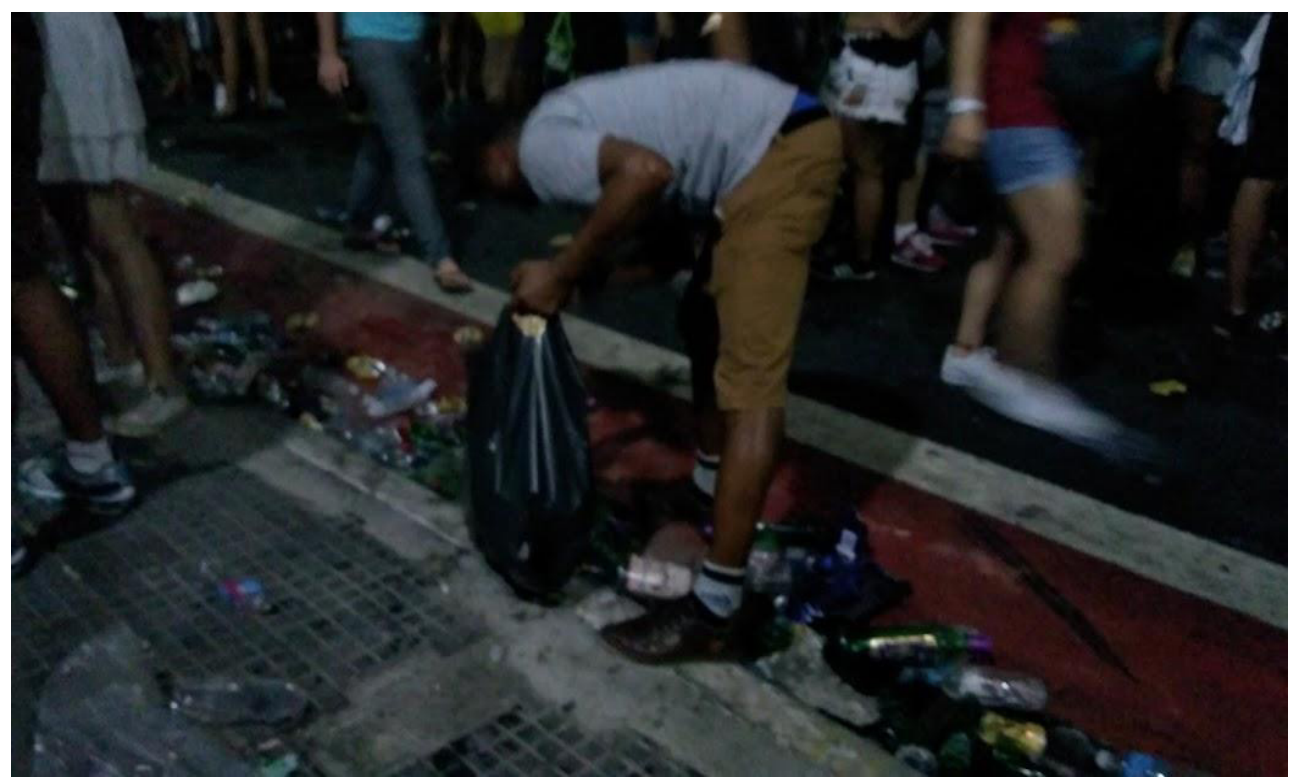

FIGURA 15 - Separação na fonte geradora - Coleta seletiva das latas de alumínio nas sarjetas que acondicionam os resíduos gerados em desfile de grande bloco. Carnaval paulistano, 2017. 


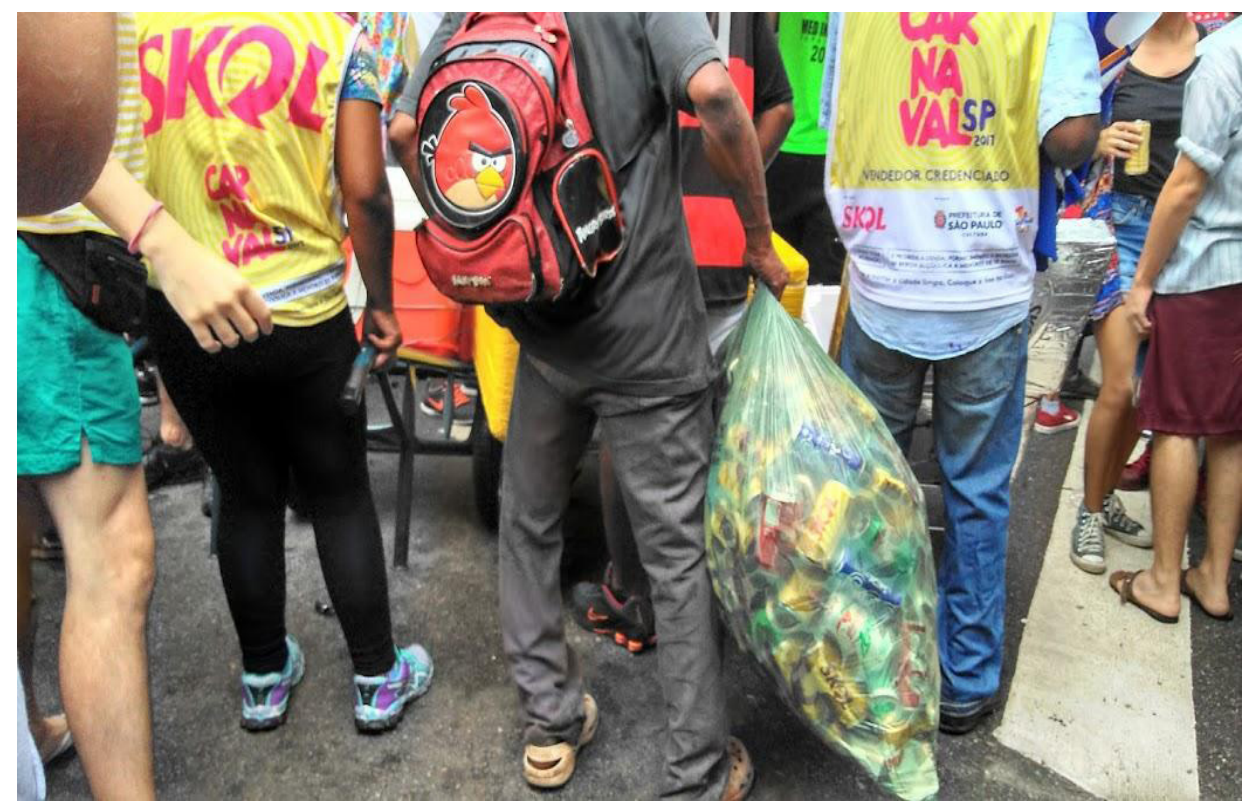

FIGURA 16 - As mochilas também podem servir como armazenamento para as latas depois de amassadas. Catador em desfile de grande bloco carnavalesco com saco do serviço público de limpeza urbana. Carnaval paulistano 2017.

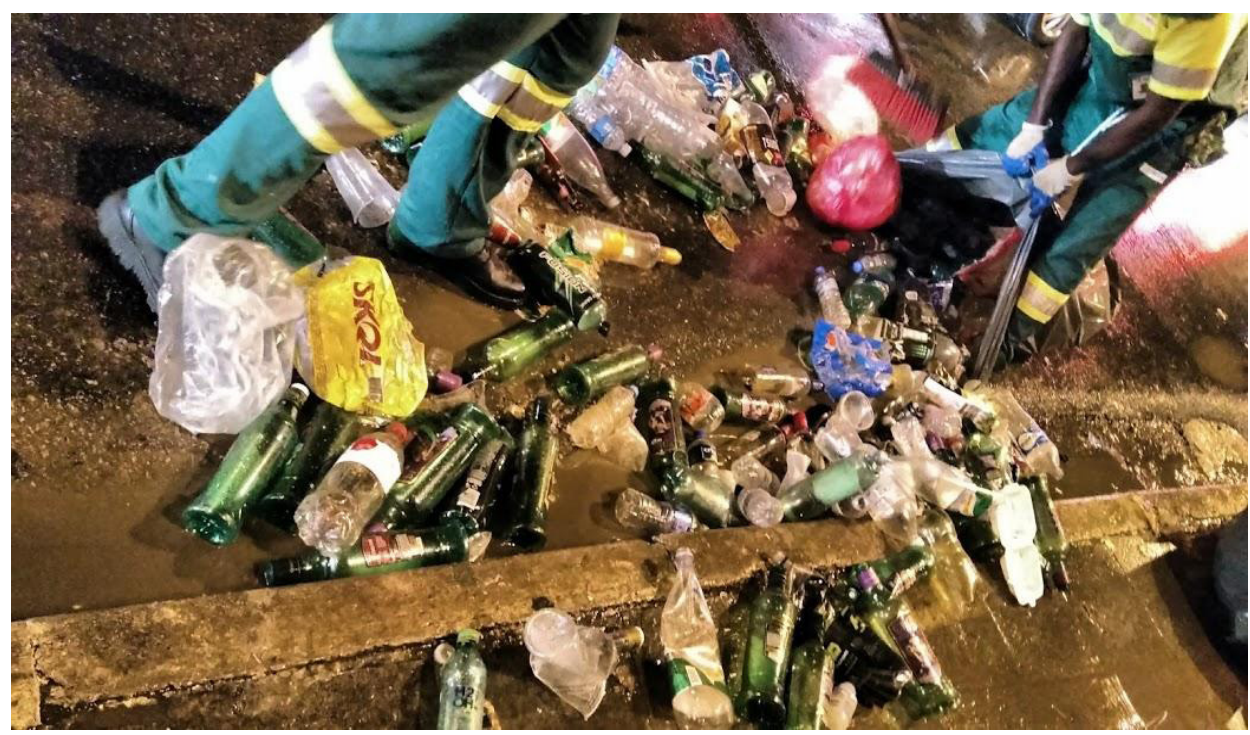

FIGURA 17 - Acondicionamento de RSU de varrição gerado no Carnaval de rua. Carnaval paulistano 2017. 
geradora pelo sistema formal de limpeza urbana. Não há sequer lixeiras suficientes disponibilizadas para o "consumidor-folião" descartar seus resíduos, os quais, após o consumo, são descartados no chão e nas sarjetas, comprometendo sobremodo a qualidade ambiental do festejo (Figura 18). Em 2017, também se destacaram os resíduos gerados por ambulantes, como filmes plásticos dos fardos de bebidas (Figuras 7, 17 e 18).

O público-folião ainda demonstra disposição para colaborar com a limpeza da festa, quando entrega a "latinha" nas mãos dos catadores, que passam às pressas a todo o momento, ou ainda, quando descartam os resíduos próximo às lixeiras, mesmo que saturadas, que, como já observado, transformam-se em "pontos" de concentração de resíduos.
Ainda, fazem o descarte em bags, ou grandes sacos, colocados em alguns pontos de grande circulação por catadores que se ocupam desse cuidado (Figura 19), uma nova prática entre os catadores observada em 2017.

Os sacos com resíduos de varrição e das lixeiras gerados na festa são armazenados em entrepostos provisórios, como observado no Carnaval de 2017 em diversos containers distribuídos na Praça da República (região central), que podem ser transportados por pequenos veículos (Figura 20), de onde então são transportados por caminhões maiores para um dos entrepostos permanentes da cidade. No caso dos grandes blocos, pode também se observar caminhões para o armazenamento e transporte dos resíduos (Figura 21).

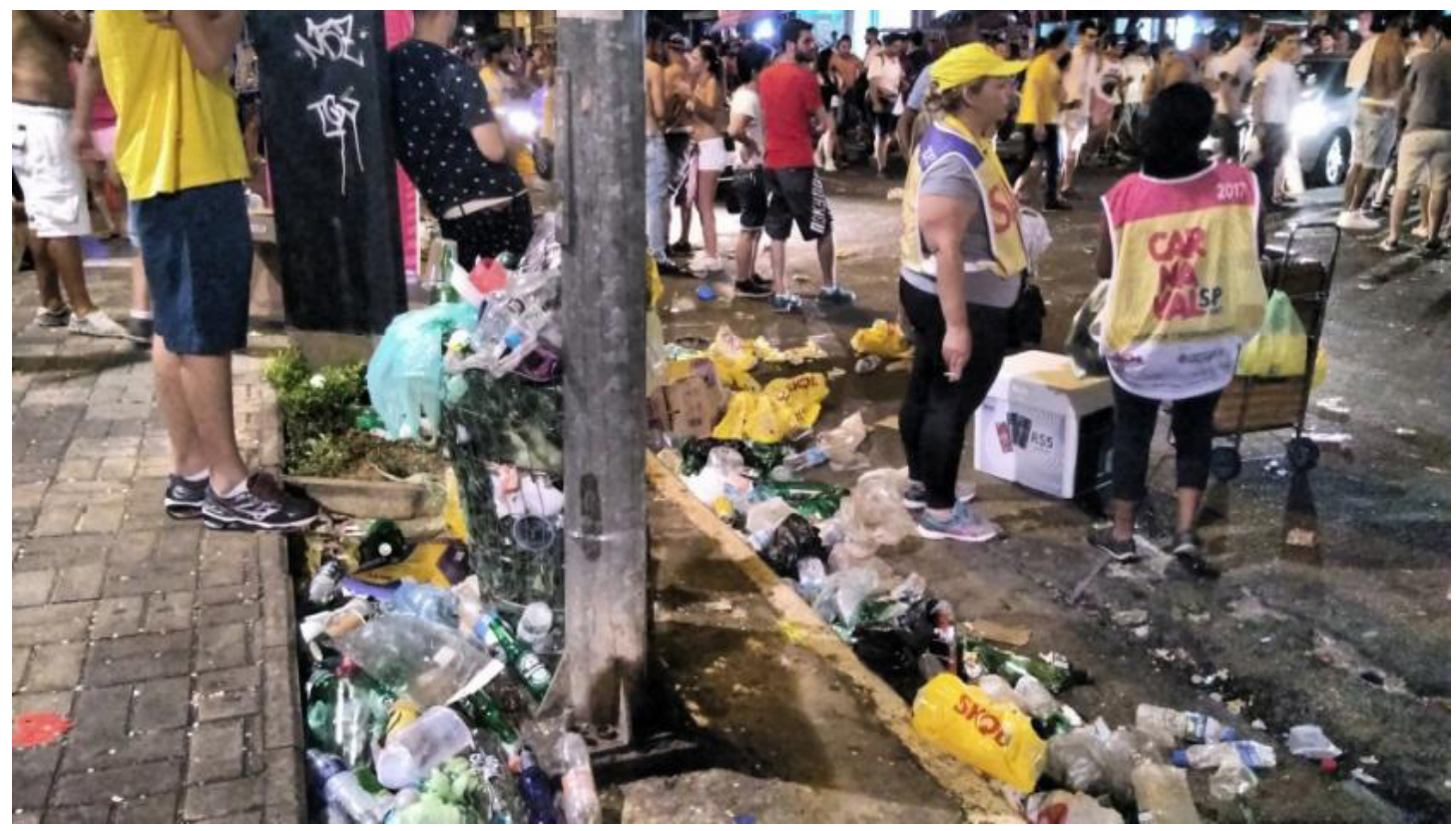

FIGURA 18 - Lixeira saturada e concentração de RSU no início da noite. Entrada da estação de metrô Fradique Coutinho. Zona Oeste. Carnaval paulistano 2017. 


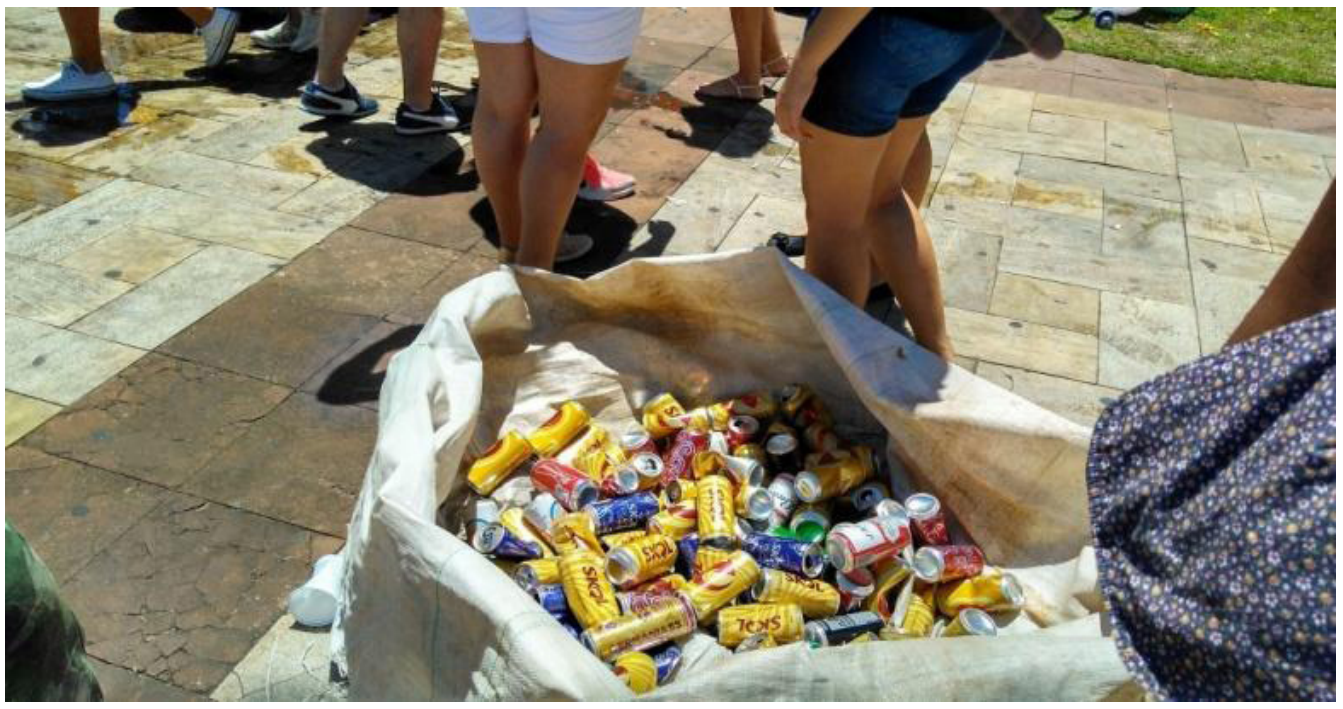

FIGURA 19 - "Bag" cuidada por catador de lata de alumínio para que não se misture demais RSU. Final da manhã. Largo da Batata, Carnaval paulistano 2017.

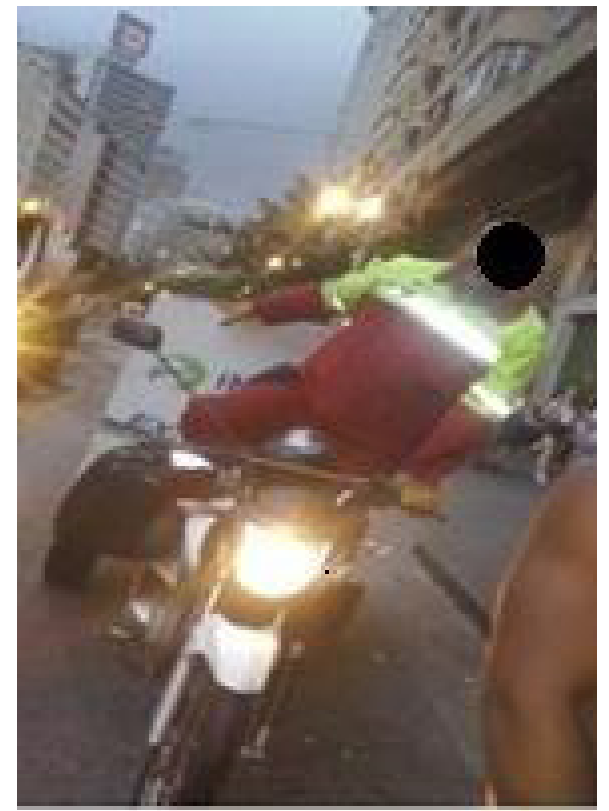

FIGURA 20 - Motocicleta para transporte de resíduos a entreposto provisório. Carnaval paulistano 2016. 


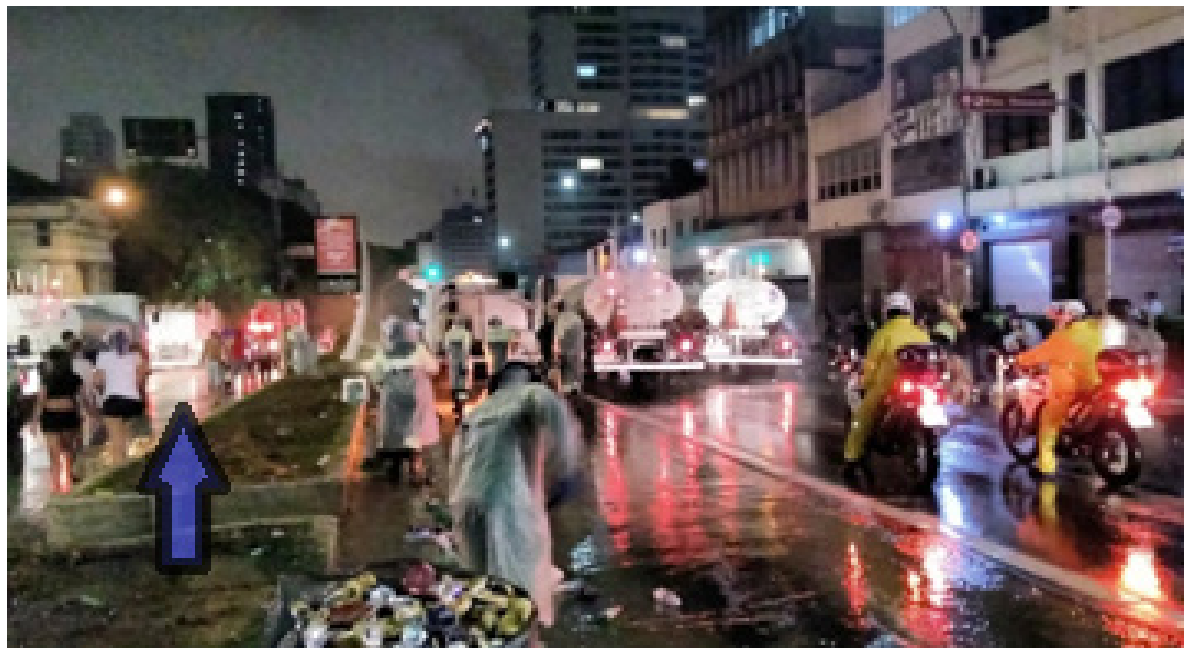

FIGURA 21 - Caminhão para armazenamento e transporte de resíduo em operação especial de limpeza de grande bloco carnavalesco. Encerramento oficial do Carnaval de rua paulistano em noite de chuva, região central, 2017.

Em 2017, a varrição hidráulica utilizada para a limpeza após o desfile de grande bloco (Figura 2), não precedida de varrição seca, observada com frequência ${ }^{17}$ na limpeza de eventos no espaço público, comprometeu o trabalho dos catadores de latinha, que realizaram a coleta parcial de latas em meio ao barulho das máquinas, à competição com a limpeza formal que as coletava junto com os demais RSU e poças d'água que se formavam nas calçadas e nas sarjetas - molhando também os pés dos últimos foliões que o acompanhavam.

\section{O Carnaval e os desafios da PNRS}

A observação da limpeza urbana e do manejo de RSU de eventos de grande porte, como o Carnaval de rua de São Paulo, mostra o comprometimento da qualidade ambiental da festa pelo grande volume de resíduos gerados, bem como a existência de dois sistemas complementares e antagônicos de limpeza urbana, que, mesmo em conjunto, não conseguem garantir a limpeza pública necessária à saúde e bem-estar de foliões, trabalhadores e moradores que ocupam o chão da festa.

O sistema informal de limpeza se estrutura pela coleta seletiva de latas de alumínio, cuja logística reversa é organizada pelo mercado e envolve o trabalho precário de catadores, que atuam ao longo de todo o festejo e reduzem o volume de RSU no ambiente festivo. A sistema formal, ao contrário, compromete a qualidade dos resíduos que, compostos em grande parte por recicláveis secos, especialmente embalagens descartáveis de plástico e vidro, são coletados sem qualquer tipo de separação e apenas ao final dos festejos. Um caso em que o serviço não reconhecido pelo poder

${ }^{17}$ Em blocos de médio e grande porte, pode-se observar a equipe de limpeza realizando varrição e coleta do resíduo a seco para lavagem posterior, em alguns casos. 
público oferece qualidade ambiental e tratamento adequado de RSU, conforme o próprio PGIRS (São Paulo, 2014), com a segregação e a coleta seletiva na fonte geradora, não realizada pelo serviço remunerado e especializado.

A segregação adequada de RSU envolve custos e informação (Viana et al., 2015), que, no caso de eventos como o Carnaval de rua, compreende desde maior número de lixeiras ou bags, como mostra o catador, e programas de educação ambiental até o transporte adequado do material. Além disso, são necessárias ações de reconhecimento e valorização do trabalho dos catadores, uma questão socioambiental associada aos eventos de grande porte em todo o país, sobretudo, de grande cobertura de mídia (local, regional ou nacional) e ao patrocínio do setor de bebidas, ocorrendo tanto no espaço público como em espaços próprios, por exemplo, no entorno dos estádios em dias de shows, clássicos e finais de campeonato.

Os tipicamente elevados recursos financeiros destinados ao tratamento adequado de resíduos configuram-se em uma questão controversa, que se coloca em todo do mundo (Demajorovic \& Lima, 2013), na qual a responsabilidade compartilhada se apresenta como instrumento para viabilizar os custos necessários ao tratamento ambientalmente adequado dos resíduos.

No caso de eventos de grande porte realizados no espaço público, a ausência da responsabilidade compartilhada se reflete na qualidade do saneamento da festa, que se transforma em "lixão temporário", abrigando um sistema perverso de exploração do trabalho. Muitos catadores não contam sequer com os sacos para a coleta, retirando-os da própria rua, também gerando problemas para a limpeza pública.
Coletando resíduos do chão, sem equipamentos de proteção e à mercê do mercado - dos preços das sucatarias, uma queixa recorrente - a alta vulnerabilidade social dos catadores reduz e até justifica, o valor do seu trabalho (Varanda \& Adorno, 2004).

Mesmo o país sendo campeão mundial de reciclagem de latas de alumínio desde 2001 (Abralatas, 2016), e com o reconhecimento pelo Estado do resíduo sólido reutilizável e reciclável como um bem econômico e de valor social, gerador de trabalho e renda e promotor de cidadania (São Paulo, 2006; Brasil, 2010), os catadores de latinha, concentrados nos eventos de grande porte e nos megaeventos, não contam com políticas capazes de melhorar suas condições de trabalho e remuneração, tampouco o acesso à assistência e direitos sociais, na promoção da cidadania.

O grande número de pessoal, de máquinas e equipamentos utilizados para a operação especial de limpeza e manejo de RSU do Carnaval de rua de São Paulo, bem como o volume de resíduos gerados - que também fazem do Carnaval de rua uma "fábrica de resíduos" - coloca algumas questões como: o quê e quanto o poder público paga em uma operação especial de limpeza urbana, como cada edição do Carnaval de rua? Quanto o poder público deixa de pagar pela limpeza informal realizada pelos catadores, também a cada edição? Quanto seria necessário para o tratamento ambientalmente adequado dos resíduos da festa, tal como a coleta seletiva na fonte geradora organizada pelos catadores de latinha ampliada para os outros materiais, com estrutura de coleta e promoção de direitos sociais?

Tais respostas poderiam também indicar o quanto a indústria do alumínio, do plástico, do vidro, de bebidas, de mídia e eventos deixam de pagar na 
ausência da aplicação do princípio da responsabilidade compartilhada e da gestão integrada ${ }^{18}$ sobre os resíduos gerados nos eventos de grande porte.

Inversamente, pode-se também perguntar quanto a indústria do alumínio, do plástico, do vidro, de bebidas, de mídia e eventos ganham com o Carnaval de rua de São Paulo. Aqui, cabem as considerações de Harvey (2009), para quem o deslocamento do espaço da competição para a escala global, como é o caso das cervejarias, fez dos bens culturais, por suas qualidades únicas e irreprodutíveis, campo de afirmação e disputa por rendimentos monopólicos ${ }^{19}$.

No entanto, expondo uma das contradições do capitalismo, o autor destaca que "a própria mercadologia tende a destruir as qualidades únicas [...] quanto mais tais itens ou eventos são facilmente comercializáveis [...], menos representarão uma base para o rendimento monopólico" (Harvey, 2009, p. 143).

A saída do grupo AB-Inbev da Marquês de Sapucaí, em 2017, a redução do seu investimento no Carnaval de Salvador (Dyniewicz, 2017) e sua ampliação para o Carnaval de rua de diversas cidades brasileiras, tal como Brasília, Belo Horizonte, Cuiabá, Manaus (Levin, 2017), aponta uma nova configuração e formatação da festa, na busca de rendimentos monopólicos. Descentralizado e in- terativo, o Carnaval de rua, promovido atualmente em diversas cidades brasileiras ${ }^{20}$, parece se complementar à rigidez dos "megacarnavais", centralizados e projetados pela TV, superando a figura do espectador-folião do Carnaval das últimas décadas.

A cultura como mercadoria precisa de sua singularidade para a obtenção de rendimentos monopólicos, o que, para Harvey (2009), a diferencia das demais mercadorias - cuja homogeneidade é pressuposta pelo sistema industrial. No entanto, no que pese sua superexploração econômica, as festas "não se deixam capturar, ou abater" (Amaral, 2012, p. 70). Mesmo reduzidas à mercadoria, como outros elementos da cultura, necessitam de originalidade, inventividade, que não se presta ao controle absoluto, e fazem do campo da cultura "espaços fundamentais de esperança para a construção de um tipo alternativo de globalização. Espaço no qual seja possível às forças progressistas da cultura tentar apropriar-se das forças do capital e miná-la, em vez do seu contrário" (Harvey, 2009, p. 170).

Porém, o que se observa, é a transformação das festas populares, símbolo e expressão de uma cultura (Amaral, 2012) e outrora identificadas como arcaicas (Farias, 2005), transformadas em negócio pelo próprio poder público, já na condição de parceiro (Farias, 2005; Frydberg et al., 2016). Muitas festas populares brasileiras, de interesse de

\footnotetext{
18 “Conjunto de ações voltadas para a busca de soluções para os resíduos sólidos, de forma a considerar as dimensões política, econômica, ambiental, cultural e social, com controle social e sob a premissa do desenvolvimento sustentável”, conforme a PNRS (Brasil, 2010).

${ }^{19}$ Para o autor, com a globalização e o fim de proteções monopólicas asseguradas pelo custo elevado do transporte e da comunicação, e a queda de barreiras alfandegárias, provocou a redução de "monopólios naturais", o que fez com que a busca de novos rendimentos monopólicos se entrelaçasse à ideia de "cultura", "exatamente porque alegações de singularidade e autenticidade podem ser mais bem articuladas como afirmações culturais distintas e não duplicáveis" (Harvey, 2009, p. 149).

20 “A Skol fará ações em 11 cidades, inclusive em algumas em que o carnaval não é reconhecido nacionalmente, como Ribeirão Preto e Campinas. Essa investida no interior paulista é reflexo do fato de uma das metas da marca para 2017 ser a expansão no estado de São Paulo. 'Investiremos em um mix de cidades mais importantes e em locais em que as festas são latentes. Estaremos onde entendemos que há potencial para aglomerar pessoas. Antes o carnaval era muito centralizado, agora alcança mais gente', diz [...] diretora de marketing” (Dyniewicz, 2017).
} 
mercado, acabam por concentrar os escassos recursos públicos destinados à cultura (Santos, 2010) e, considerando-se que as maiores despesas para a realização de eventos são com espaço e infraestrutura $^{21}$ (ABEOC, 2014), acabam por se transformar em mecanismo de exploração em cadeia da cultura, do espaço público e do trabalho precário de catadores e ambulantes, cujo consumo de embalagens descartáveis para bebidas ${ }^{22}$ se expressa na geração espetacular de resíduos sólidos urbanos do/no espaço festivo, em um processo de subordinação do espaço público ao controle privado (Arantes, 2002).

Se a transformação da cultura em mercadoria não é algo novo, cabe destacar os novos mecanismos institucionais, como a Lei Rouanet (Arruda, 2003) e a formação de um mercado do simbólico (Farias, 2005), amparado no novo arsenal tecnológico, científico e informacional, em que "a técnica é a grande banalidade e o grande enigma" (Santos, 1997, p. 20).

Tanto na banalidade de latas que voltam a ser latas, das máquinas de cartão sem fio, dos aplicativos de celulares e dos sites para cadastro de ambulantes, na normalização do trabalho precário (Arantes, 2002) como no enigma da mais-valia digital, dos cabos de fibra ótica, das multiplataformas integradas e conglomerados multimídia, sobre os quais, em tempos de infoentretenimento, "agrupam-se os mais diversos atores econômicos, atraídos pela oportunidade de alavancar seus negócios" (Moraes, 2013, p. 22), nota-se que o Carnaval da interatividade digital vai se remodelando no país.
Na confluência do consumo e do entretenimento, a transformação das cervejarias em "promotoras de eventos" e seus impactos sobre um bem simbólico-afetivo (Farias, 2005), como o Carnaval no Brasil, colocam em questão o interesse público na sua atual conformação, especialmente, no que se refere à saúde pública, que vai além do saneamento do ambiente festivo.

Conforme Vendrame \& Pinsk (2011), estudos nacionais e internacionais indicam que o conteúdo das mensagens publicitárias atua no processo de tomada de decisão do indivíduo para o consumo de álcool. No que pese a justificativa do setor para os maciços investimentos em publicidade se limitar à fidelidade de marca - e não ao aumento do consumo -, "estudos já demonstraram que apresentar fidelidade a uma marca, isoladamente, pode predizer consumo em maior quantidade de álcool" (Vendrame \& Pinsk, 2011, p. 197).

Cabe também perguntar o quanto de marketing e publicidade se traduz nos RSU gerados no Carnaval de rua de São Paulo, pois, como destacam os autores: "Em relação ao carnaval, por exemplo, a indústria cervejeira admite, em seu relatório anual, a existência de aumento do consumo como resultado de um esforço maior em publicidade" (Vendrame \& Pinsk, 2011, p. 194). Desse modo, o acesso à informação, bem como o controle social, previstos na PNRS, apresentam-se como ferramentas importantes na aplicação do princípio da gestão integrada de resíduos (Brasil, 2010) no contexto dos eventos de grande porte, que se multiplicam pelo país. Antes

\footnotetext{
${ }^{21}$ Conforme pesquisa recente, os maiores gastos na realização de eventos são com espaço (23\%), infraestrutura e equipamentos (18\%), e os menores, com palestrantes/artistas (5\%) e marketing e promoção (6\%) (ABEOC, 2014).

${ }^{22}$ Cabe destacar que, para o consumidor, nas bebidas em embalagem retornável, paga-se apenas a bebida, enquanto que o consumo de bebida em embalagem descartável, paga-se também pela embalagem (Cervieri Junior et al., 2014).
} 
de tudo, não se trata apenas de mais lixeiras, e sim, de menos resíduos.

A forte presença das cervejarias globais no Carnaval e sua influência na organização da festa que, no Brasil, ganha status de identidade nacional, deve ainda ser mais bem compreendida, posto que envolve o incentivo ao consumo de seus produtos in loco, bem como o fortalecimento de suas marcas, com diversos ganhos associados ao simbolismo da festa. Observando o Carnaval de Salvador e Recife, "megacarnavais" televisionados que conservaram o formato de rua, Santos (2010, p. 72) destaca:

A análise do resultado econômico-financeiro da Ambev [...] parece evidenciar a distorção provocada pela Lei Rouanet. Isso significa que, ao patrocinar a festa, a empresa obtém benefícios fiscais, por um lado. E, por outro, tem também um excelente nível de vendas, já que os comerciantes ficam obrigados a comprar apenas produtos da empresa e nem sempre em condições favoráveis ou justas. A Ambev, portanto, ganha nas "duas pontas", e, nesse sentido, apontá-la como uma das maiores beneficiárias do carnaval não parece exagero.

Depreende-se, portanto, que o renascimento do Carnaval de rua de São Paulo se insere em um contexto mais amplo, marcado pela "reviravolta cultural em favor do mercado" (Arantes, 2002, p. 67), que pode ser vista no seio da expansão do setor de lazer e turismo, fortemente promovido pelas cidades em todo o mundo, como meio de diferenciação e captação de divisas (Castells \& Borja, 1996; Vargas, 1998; Waterman, 1998; Arantes, 2002; Horne, 2010), quadro bastante distinto do Carnaval reprimido do Largo da Banana do período industrial. Aqui, a valorização de bens culturais e das especificidades locais mostra-se fundamental, porém, para a promo- ção do consumo e para o crescimento econômico, especialmente, das grandes corporações.

\section{Referências}

ABEOC. Associação Brasileira de Empresas de Eventos. II Dimensionamento Econômico da Indústria de Eventos no Brasil-2013, 2014. Disponível em: $<$ http://www.abeoc.org. br/wp-content/uploads/2014/10/II-dimensionamento-setor-eventos-abeoc-sebrae-171014.pdf>. Acesso em jan.2016.

ABRALATAS. Associação Brasileira de Fabricante de Latas de Alta Reciclabilidade. Mundo: índices de reciclagem da lata de alumínio para bebidas (1991 a 2015). Disponível em: $<$ http://www.abralatas.org.br/grafico/grafico-8/>. Acesso em: dez. 2016.

ABRALATAS. Cade reconhece monopólio das chapas. 15 de ago. 2009. Disponível em <http://www.abralatas. org.br/cade-reconhece-monopolio-da-chapa/> . Acesso em: jun. 2017.

Andrade, M. L. A.; Vieira, J. R. M.; Cunha. M.S. Latas para cervejas e refrigerantes: o desafio alumínio $\mathrm{X}$ aço. BNDES Setorial. 7, 3 -28, 1998. Disponível em: <https://web.bndes. gov.br/bib/jspui/handle/1408/2480>. Acesso em: ago. 2017.

Amaral, R. Para uma antropologia da festa: questões metodológico-organizativas do campo festivo brasileiro. In: PEREZ, L.F.; AMARAL, L.; MESQUITA, W. F. (Orgs.). Festa como perspectiva e em perspectiva. Rio de Janeiro: Garamond, 2012.

Amarante, L. Largo da Banana, onde nasceu o Memorial. Revista do Memorial da América Latina, 48, 14-17, 2013. Disponível em: < http://www.memorial.org.br/wp-content/ uploads/2007/03/revista48-port.pdf. >. Acesso em: dez. 2016.

Arantes, O. Uma estratégia fatal - A cultura nas novas gestões urbanas. In. Arantes, O.; Vainer, C.; Maricato, E. (Orgs.). A cidade do pensamento único. Desmanchando consensos. Petrópolis: Vozes, p. 11-74, 2002.

Arruda, M. A. N. A política cultural: regulação estatal e mecenato privado. Tempo Social, 15 (2), 178-193, 2003. 
Azevedo, A. M. Sambas, orixás e arranha-céus: a música de Geraldo Filme. Cadernos de Pesquisa do CDHIS, 25 (1), p. 47- 69, 2012.

Azevedo, A. M. São Paulo Negra: Geraldo Filme e a geografia do samba paulista. Revista da ABPN, 6 (13), 313-328, 2014.

Belo, V. L. O enredo do carnaval nos enredos da cidade. Dinâmica Territorial das escolas de samba em São Paulo. São Paulo, Dissertação (Mestrado em Geografia Humana) - USP, 2008.

Brasil. Lei n. 12.305 de 02 de agosto de 2010. Institui a Política Nacional de Resíduos Sólidos; altera a Lei no 9.605, de 12 de fevereiro de 1998; e dá outras providências. DOU de $3 / 08 / 2010$.

Brasil. Lei n. 11.445 de 5 de janeiro de 2007. Estabelece diretrizes nacionais para o saneamento básico; altera as Leis $\mathrm{n}^{\mathrm{os}}$ 6.766, de 19 de dezembro de 1979, 8.036, de 11 de maio de 1990, 8.666, de 21 de junho de 1993, 8.987, de 13 de fevereiro de 1995; revoga a Lei no 6.528 , de 11 de maio de 1978; e dá outras providências. DOU de 08/01/2007.

Cabral, S.; Krane, D.; Dantas, F. A Dança dos blocos, empresários, políticos e técnicos: condicionantes da dinâmica de colaboração interorganizacional do carnaval de Salvador. Organizações e Sociedade, 20 (64), 145-163, 2013.

Carnaval de rua de São Paulo se torna um dos maiores do país com 495 blocos inscritos. 05 de fev. 2017. Rede Brasil Atual. Disponível em $<\mathrm{http}$ :/www.redebrasilatual.com.br/ entretenimento/2017/02/carnaval-de-rua-de-sao-paulo-se-torna-um-dos-maiores-do-pais-com-495-blocos-inscritos> . Acesso em: ago. 2017.

Carvalho, M.; Gagliardi, C. Setor de turismo como indicador da reconfiguração metropolitana de São Paulo. In: Carvalho, M.; Gagliardi, C. (Orgs.). Megaprojetos, Megaeventos, Megalópole: a produção de uma nova centralidade em São Paulo. São Paulo: Olhos d'Agua, p. 35-51, 2015.

Castells, M.; Borja, J. As cidades como atores políticos. Novos Estudos CEBRAP, 45, 152-166, 1996.

Cervieri Junior, O.; Teixeira Junior, J. R.; Galinari, R.; Rawet, L.; Silveira, C. T. J. O setor de bebidas no Brasil. BNDES Setorial, 40, 93-130, 2014. Disponível em: <https://
web.bndes.gov.br/bib/jspui/bitstream/1408/3462/1/BS\%20 40\%20O\%20setor $\% 20 \mathrm{de} \% 20$ bebidas $\% 20$ no\%20Brasil_P. pdf >. Acesso em: jun. 2017.

Coutinho, E. G. Os Cronistas de Momo - Imprensa e Carnaval na Primeira República. Rio de Janeiro: Editora UFRJ, 2006.

Costa, S. S. A implementação da Política Nacional de Resíduos Sólidos no Brasil: três anos após sua sanção - o que já foi feito. In: Santos, M. C. L. (Org.). Design, Resíduos \& Dignidade. São Paulo: Olhares, p. 159-162, 2014.

Debord, G. A sociedade do espetáculo. Rio de Janeiro: Contraponto, 1997.

Demajorovic, J.; Lima, M. Cadeia de reciclagem: um olhar para os catadores. São Paulo: Editora Senac SP, 2013.

Dyniewicz, L. Marcas trocam o camarote pelas ruas. O Estado de São Paulo, São Paulo, 06 fev.2017. Disponível em: $<$ http://economia.estadao.com.br/noticias/negocios,marcas-trocam-os-camarotes-pelas-ruas, 70001654278>. Acesso em: ago. 2017.

Farias, E. Economia e cultura no circuito das festas populares brasileiras. Sociedade e Estado, 20 (3), 647-688, 2005.

Frydberg, M.; Kossak, A; Machado, G.P.O. Bloco Produto e o Produto no Bloco: Tensões e Relações entre Economia e Cultura no Carnaval dos Blocos de Rua do Rio de Janeiro. In: Anais do VIII Encontro Nacional de Estudos do Consumo. Niterói, RJ. Novembro/2016.

Godoy, S.R. Muito além da lata de lixo: a construção da política pública e a organização do mercado de limpeza urbana no município de São Paulo. São Paulo, Dissertação (Mestrado em Ciência Política) - USP, 2015.

Harvey, D. A condição pós-moderna: uma pesquisa sobre as origens da mudança cultural. São Paulo: Loyola, 2008.

Harvey, D. A arte de lucrar: globalização, monopólio e exploração da cultura. In. Moraes, D.(Org.). Por uma outra comunicação - Mídia, mundialização cultural e poder. Rio de Janeiro; São Paulo: Record, 2009.

Herschmann, M. Apontamentos sobre o crescimento do Carnaval de rua no Rio de Janeiro no início do século 21. Intercom - Revista Brasileira de Ciências da Comunicação. 
36, (2), 267-289, 2013.

Horne, J.D. Cricket in Consumer Culture: Notes on the 2007 Cricket World Cup. American Behavioral Scientist, 53 (10), 1549- 1568, 2010.

Layargues, P. O cinismo da reciclagem: o significado ideológico da reciclagem da lata de alumínio e suas implicações para a educação ambiental. In: Loureiro, F.; Layargues, P.; Castro, R. (Orgs.). Educação ambiental: repensando o espaço da cidadania. São Paulo: Cortez, p.179-220, 2002.

Levim, T. Marcas de cerveja já estão prontas para a folia. Meio e Mensagem, 16 fev.2017. Disponível em: $<$ http://www.meioemensagem.com.br/home/marketing/2017/02/16/as-acoes-das-cervejas-no-carnaval.html $>$. Acesso em: ago. 2017.

Lima, D. R. O fenômeno da reciclagem de lata de alumínio no Brasil: inovação tecnológica, oligopólios e catadores. Brasília, Dissertação (Mestrado em Política e Gestão Ambiental) - UnB, 2007.

Little, P. E. Os desafios da Política Ambiental no Brasil. In: Little, P. E. (Org.). Políticas Ambientais no Brasil - Análises, Instrumentos e Experiências. São Paulo: Peirópolis; Brasília, IIEB, p. 13-24, 2003.

Marques, R. M. F.; Melo, M. M. Folia Midiática: Breve História da Participação da Imprensa na Construção do Carnaval Carioca. In: Anais do XXXVIII Congresso Brasileiro de Ciências da Comunicação. Rio de Janeiro, RJ. Setembro/2015.

Montes, V. A.; Coriolano, L. N. M.T. Turismo de eventos: promoções e parceiras no Brasil. Turismo em Análise, 14 (1), 40-64, 2003.

Moraes, D. Sistema midiático, mercantilização cultural e poder mundial. In: Moraes, D.; Ramonet, I.; Serrano, P. (Orgs.). Mídia, Poder e Contrapoder: Da concentração monopólica à democratização da informação. São Paulo: Boitempo; Rio de Janeiro: FAPERJ, p. 19-52, 2013.

Oliveira, C.D.M. Geografia do turismo na cultura carnavalesca. São Paulo: Paulistana, 2007.

Rolnik, R. Dramas e Delícias do Carnaval. Folha de São Paulo. São Paulo, 09 fev. 2015. Disponível em:<http:// www1.folha.uol.com.br/colunas/raquelrolnik/2015/02/ 1587229-dramas-e-delicias-do-carnaval.shtml>. Acesso em: nov. de 2016.

Santos, F.B. P. Carnaval e administração pública: o papel dos governos locais na configuração das festas. Textos escolhidos de cultura e arte populares, 7(2), 61-74, 2010.

Santos, M.C.L. Lições das cidades de plástico e papelão: resíduos, design e o panorama visto da margem. In: SANTOS, M.C.L. (Org.). Design, Resíduos \& Dignidade. São Paulo: Olhares, p. 41-56, 2014.

Santos, M. Técnica, Espaço, Tempo - Globalização e meio técnico-científico-informacional. São Paulo: Hucitec, 3. ed.,1997.

São Paulo. (Estado). Lei 12.300 de 16 de março de 2006. Institui a Política Estadual de Resíduos Sólidos e define princípios e diretrizes. DOE de 17/03/2006.

São Paulo. (Município). Decreto 56.690 de 7 de dezembro de 2015. Disciplina o Carnaval de Rua da Cidade de São Paulo. São Paulo, 2015a. DOM de 8/12/2015.

São Paulo. Lei 7.100, de 29 de dezembro de 1967. Dispõe sobre a promoção de festas de cunho popular e festejos carnavalescos, e dá outras providências. DOM de 30/12/1967.

São Paulo. Plano de Gestão Integrada de Resíduos Sólidos. 2014. Disponível em: <http://www.prefeitura.sp.gov.br/ cidade/secretarias/upload/servicos/arquivos/PGIRS-2014. pdf >. Acesso em: dez.2016.

São Paulo. Secretaria Especial de Comunicação. Carnaval de rua de São Paulo terá 391 blocos com desfiles em várias regiões. 12 fev. 2017. Disponível em: <http://www.capital. sp.gov.br/noticia/carnaval-de-rua-de-sp-tera-391-blocos-com-desfiles-em-varias-regioes>. Acesso em: ago. 2017.

São Paulo. Secretaria Municipal de Cultura. Edital de Chamamento Público - Carnaval de rua (Processo n ${ }^{\circ} 2015$ 0.238.097-4). Ata de Reunião. DOM, 9/12/2015b.

São Paulo. Secretaria Municipal de Cultura. Prefeitura de São Paulo detalha o Plano de Apoio ao Carnaval de Rua de São Paulo. 28 jan. 2016a. Disponível em: <http://carnavalderua.prefeitura.sp.gov.br/prefeitura-de-sao-paulo-detalha-o-plano-de-apoio-ao-carnaval-de-rua-de-sao-paulo/>. Acesso em: nov. 2016. 
São Paulo. Secretaria Municipal de Cultura. Cadastramento dos Blocos e Cordões Carnavalescos de São Paulo 2017. 29 set. 2016b. Disponível em: $<$ http://carnavalderua.prefeitura. sp.gov.br/cadastramento-dos-blocos-e-cordoes-carnavalescos-de-sao-paulo-2017>. Acesso em: nov. 2016.

São Paulo. Secretaria Municipal de Cultura. Edital de Chamamento Público (Carnaval de Rua 2017). São Paulo, 2016c. Disponível em: < http://carnavalderua.prefeitura. sp.gov.br/wp-content/uploads/2016/08/EDITAL-DE-CHAMAMENTO-P\%C3\%9ABLICO-Carnaval-de-Rua-2017 Final.pdf>. Acesso em: ago. 2017.

Simson, O. R. M. von. Carnaval em Branco e Negro: Carnaval Popular Paulistano 1914-1988. Campinas: Editora da Unicamp; São Paulo: Editora da Universidade de São Paulo; Imprensa Oficial do Estado de São Paulo, 2007.

Souza, L.S. L. O êxodo do samba: do rural ao trabalho discursos sobre a resistência negra em São Paulo. Lingua, Literatura e Ensino, 4, 341-345, 2009.

Varanda, W.; Adorno, R.C. F. Descartáveis urbanos: discutindo a complexidade da população de rua e o desafio para políticas de saúde. Saúde e Sociedade, 13 (1), 56-69, 2004.
Vargas, H. C. Turismo e valorização do lugar. Turismo em Análise, 9 (I), 7- 19, 1998.

Viana, H. Tradição da Mudança: A Rede das Festas Populares Brasileiras. Revista do Patrimônio Histórico e Artístico Nacional, 32, 302-215, 2005.

Viana, E.; Silveira A. I.; Martinho, G. Caracterização de resíduos sólidos. Uma abordagem metodológica e propositiva. São Paulo: Biblioteca 24 horas, 2015.

Vendrame, A.; Pinsky, I. Ineficácia da autorregulamentação das propagandas de bebidas alcoólicas: uma revisão sistemática da literatura internacional. Revista Brasileira de Psiquiatria, 33 (2), 196-202, 2011.

Waterman, S. Carnivals for Elites? The Cultural Politics of Arts Festivals. Progress in Human Geography, 22 (1), 54-74, 1998. 